\title{
Cytokine-Mediated Hepatic Apoptosis
}

\author{
M. Leist ${ }^{1}$, F. Gantner ${ }^{2}$, G. Künstle ${ }^{2}$, and A. Wendel ${ }^{2}$ \\ ${ }^{1}$ Chair of Molecular Toxicology, Faculty of Biology, University of Konstanz, \\ POB X911, 78457 Konstanz, Germany \\ ${ }^{2}$ Chair of Biochemical Pharmacology, Faculty of Biology, University of Konstanz
}

\section{Contents}

1 Introduction . . . . . . . . . . . . 110

2 Apoptosis vs Necrosis: Definitions and Delimitations . . . . . 110

3 Evidence for Apoptosis in the Liver . . . . . . . . . . 114

3.1 Historical Aspects . . . . . . . . . . . . . . 114

3.2 Inflammation and Hepatic Apoptosis . . . . . . . 115

3.3 Viral Disease and Apoptosis . . . . . . . . . . . 116

3.4 Apoptosis Induced by Toxins and Organ Size Regression . . 118

4 Hepatic Apoptosis Elicited by Cytokine Signaling . . . . . . . . 118

4.1 Transforming Growth Factor- $\beta \ldots \ldots \ldots \ldots \ldots$

4.2 Tumor Necrosis Factor . . . . . . . . . . . . . . . . . 119

4.2.1 Studies in Hepatocyte Cultures . . . . . . . . . . . 120

4.2.2 In Vivo Studies in Mice . . . . . . . . . . . . . . 122

4.2.3 LPS-Induced Endogenous Production of TNF . . . . . . 123

4.2.4 Induction of Endogenous TNF by Stimuli Other Than LPS . 124

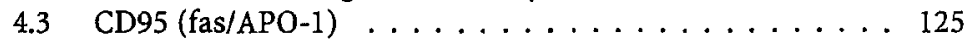

4.3 .1 Studies in Hepatocyte Cultures . . . . . . . . . . 126

4.3 .2 In Vivo Studies in Mice . . . . . . . . . . . . . . . 126

4.4 Delimitation of the CD95/CD95L System and the TNF-R/TNF System . . . . . . . . . . 127

5 Mechanisms and Modulation of Hepatic Apoptosis . . . . . . 128

5.1 Key Mechanisms of Apoptosis . . . . . . . . . . . 130

5.2 Pharmacological Prevention of Apoptosis . . . . . . . . 131

5.3 Immunological and Genetic Modulation of Apoptosis . . 133

6 Apoptosis in Hepatotoxicology . . . . . . . . . . . . . 134

6.1 Mediators Derived From Non-parenchymal Cells and Cytokines in Hepatotoxicology . . . . . . . . 135

6.2 Toxin-Induced Apoptosis . . . . . . . . . . . . . 136

6.3 TNF as Mediator of Toxin-Induced Apoptosis . . . . . . 136

References . . . . . . . . . . . . . . . 138 


\section{Introduction}

Thirty years ago liver pathology defined apoptosis as a novel mode of cell death. Recently, experimental models of liver injury have been made available for examining the signaling molecules and receptors of apoptotic mechanisms as well as their pathological relevance. Experimental evidence suggests the involvement of apoptosis not only in various inflammatory liver disorders, but also in conditions of poisoning with xenobiotic hepatotoxins. The presence of several differentially regulated apoptosismediating receptors and their ligands on hepatocytes may explain the liver's susceptibility to autoimmune reactions, toxins, and viruses causing chronic liver disease, as well as the differential sensitivity of this system in various metabolic and pathologic conditions.

Tumor necrosis factor (TNF) and its receptors (TNF-R), as well as CD95L and its receptor (CD95), are well-known cytokine/cytokine receptor systems relevant to hepatic disease and to apoptosis. Neutralization of endogenously released TNF prevents hepatocyte apoptosis associated with inflammatory liver damage. Direct injection of TNF in sensitized mice results in large scale hepatocyte apoptosis which is exclusively and selectively mediated by the $55-\mathrm{kDa}$ TNF-R. Fulminant apoptotic liver damage is also triggered upon stimulation of CD95. Possible triggering cells include hepatocytes that express CD95L under pathological conditions. Despite the lack of interaction between TNF-R and CD95 on the receptor level, their signal transduction inside the cell seems to involve common proteolytic steps since inhibition of proteases of the caspase family blocks hepatocyte death, liver damage, or lethality in mice signaled by either receptor.

\section{2}

\section{Apoptosis vs Necrosis:} Definitions and Delimitations

Despite early pioneering studies of pathologists and developmental biologists on programmed cell death in regressing organs and during development, up until the late 1960 s cell death had been mostly regarded as a passive and barely regulated event that follows excessive disturbances of cellular homeostasis (see review in Majno and Joris 1995). Up to that time 
mechanisms of cell death had been exclusively studied in tissues of multicellular organisms and the events following cell death on the tissue level were termed necrosis. Nowadays, cell death has become an important topic in biochemistry, cell biology, immunology, and molecular biology. In these fields the word necrosis is often used to describe a type of cell demise characterized by edema, swelling, and dysfunction of intracellular organelles, with rupture of the cell membrane and without precedent packaging and ordered fragmentation of the chromatin (for the purposes of this chapter we follow this definition). Since, strictly speaking, the term necrosis refers to post-mortem events in tissues, alternative terms such as oncosis or lytic cell death have been suggested for the description of the above mode of cell demise (Majno and Joris 1995). Although historically more correct these terms are generally less common.

A different form of cell death with a distinct morphology was first described more than 100 years ago (Flemming 1885; Councilman 1890; Nissen 1886; Pfitzner 1886). This form of cell death was finally classified as a morphological entity of its own (Table 1) with distinct conceptual implications by Kerr, Wyllie, and Currie, and eventually named apoptosis (Kerr et al. 1972). Its defining features include: shrinkage of the cell, detachment from neighboring cells, preservation of the morphological structure of intracellular organelles, packaging and specific fragmentation of the chromatin, and specific cell membrane alterations indicating the readiness to be phagocy tosed. Apoptosis is an inconspicuous type of cell death, allowing rapid removal of the dying cell to prevent tissue damage and inflammation that would otherwise be caused by spilt cell contents (Gräper 1914; Savill et al. 1993). In addition, apoptosis favors rapid reorganization of the tissue to the original structure, and avoids leakiness of epithelia such as that formed by gut brush border cells. Accordingly, patients may recover from massive, probably apoptotic, hepatocyte loss during fulminant viral hepatitis without scarring (Karvountzis et al. 1974). In cell cultures exposed to apoptotic stimuli or in pathological situations associated with an extremely high rate of synchronized apoptosis, cells cannot be taken up by phagocytosis and eventually lyse. This process of secondary lysis of originally apoptotic cells is often confusingly called secondary necrosis or apoptotic necrosis. However, this post-mortem process does not seem to be related to necrotic/lytic/oncotic cell demise (which describes the transition of living to dead cells).

In parallel to the pathological characterization of apoptosis, developmental biologists discovered a form of "natural" cell death, occurring 
Table 1. Distinguishing features of apoptosis and necrosis

\begin{tabular}{|c|c|c|}
\hline & Apoptosis & Necrosis \\
\hline Nucleus & $\begin{array}{l}\text { Condensation and margination } \\
\text { of chromatin, often to } \\
\text { characteristic crescent-shaped } \\
\text { figures. Very frequenty } \\
\text { disintegration into sharply } \\
\text { delineated spherical chromatin } \\
\text { masses that are eventually } \\
\text { scattered throughout the cytosol }\end{array}$ & $\begin{array}{l}\text { Occasionally condensation } \\
\text { (pyknosis) at initial stages; later } \\
\text { mostly disintegration (karyorrhexis) } \\
\text { and dissolution (karyolysis). On } \\
\text { light microscopic level, early } \\
\text { pyknotic stages may sometimes } \\
\text { resemble apoptosis }\end{array}$ \\
\hline Cytoplasm & $\begin{array}{l}\text { Condensation of cytosol. Dense } \\
\text { packaging of relatively intact } \\
\text { organelles. Occasional dilatation } \\
\text { of endoplasmic reticulum. } \\
\text { Occasionally pronounced } \\
\text { autophagic vacuolization }\end{array}$ & $\begin{array}{l}\text { Edematous swelling of organelles } \\
\text { and rupture of intracellular } \\
\text { membranes }\end{array}$ \\
\hline $\begin{array}{l}\text { Tissue } \\
\text { distribution }\end{array}$ & $\begin{array}{l}\text { Mostly affecting scattered single } \\
\text { cells. Detachment of apoptotic } \\
\text { cells from neighboring cells and } \\
\text { rounding up }\end{array}$ & $\begin{array}{l}\text { Often contiguous groups of cells } \\
\text { are affected. Often, no retraction/ } \\
\text { rounding up of affected cells, but } \\
\text { rather closure of intercellular gaps } \\
\text { due to edema }\end{array}$ \\
\hline $\begin{array}{l}\text { Plasma } \\
\text { membrane }\end{array}$ & $\begin{array}{l}\text { Loss of microvilli; blebbing } \\
\text { (zeiosis) with maintenance of } \\
\text { membrane integrity until cells } \\
\text { are phagocytosed; display of } \\
\text { phagocytosis signals; rapid active } \\
\text { loss of lipid assymetry }\end{array}$ & $\begin{array}{l}\text { Blebbing, leading eventually to } \\
\text { rupture of plasma and spillage of } \\
\text { intracellular contents }\end{array}$ \\
\hline $\begin{array}{l}\text { DNA } \\
\text { fragmentation }\end{array}$ & $\begin{array}{l}\text { Characteristic high molecular } \\
\text { weight DNA fragmentation into } \\
50-\mathrm{kb} \text { and } 300-\mathrm{kbp} \text { fragments. } \\
\text { In many cases oligonucleosom- } \\
\text { al cleavage into } \mathrm{n} \times 180-\mathrm{bp} \text { DNA- } \\
\text { fragments }\end{array}$ & $\begin{array}{l}\text { Sometimes random DNA } \\
\text { degradation. Often little DNA } \\
\text { degradation before lysis of the } \\
\text { plasma membrane }\end{array}$ \\
\hline Phagocytosis & $\begin{array}{l}\text { Rapid removal by professional } \\
\text { phagocytes and by neighboring } \\
\text { cells }\end{array}$ & $\begin{array}{l}\text { Clearance of necrotic tissue by } \\
\text { infiltrating phagocytes after } \\
\text { disintegration of cells }\end{array}$ \\
\hline $\begin{array}{l}\text { Tissue } \\
\text { reaction }\end{array}$ & $\begin{array}{l}\text { Mostly inconspicuous; mostly } \\
\text { reconstitutio ad integrum; often } \\
\text { apoptosis necessary for tissue } \\
\text { organization }\end{array}$ & $\begin{array}{l}\text { Often inflammatory response, } \\
\text { leukocyte infiltration, production } \\
\text { of immune mediators; often } \\
\text { formation of scar tissue or } \\
\text { disturbance of tissue organization }\end{array}$ \\
\hline
\end{tabular}


without severe external insult, but often involving de novo gene induction (Glïcksmann 1951; Schwartz and Osborne 1993; Saunders 1966; Lockshin and Beaulaton 1974). Certain cells seemed to be destined (or "programmed") to die at a given stage of development at a given location. In fact, this process of creation of cells that would be eliminated according to a predetermined scheme had already been outlined in 1858 by Virchow in his lecture on atherosclerosis: "Thus, we have here an active process which really produces new tissue, but then hurries on to destruction in consequence of its own development" (Virchow 1858). It is now clear that most of this so-called programmed developmental cell death is characterized by apoptotic morphology. The terms apoptosis and programmed cell death are therefore currently used as synonyms, although forms of programmed cell death (especially in multinucleated muscle cells) without apoptotic morphology may exist (Schwartz et al. 1993; Lockshin and Williams 1965). Notably, it is now evident that there is no absolute requirement of gene induction for programmed cell death or apoptosis to occur. Transcription may be required in many instances in the signaling phase of apoptosis to create a metabolic situation in the cell that would cause a constitutively present core program to be executed (Weil et al. 1996). This core program may be conceived as the series of partially self-regulatory steps, beyond the signaling phase, that can lead to cell demise. Since the proper execution of these steps commonly results in apoptotic morphology, the term apoptosis has gained a conceptual aspect in addition to its original strictly morphological definition.

Recent observations suggest that apoptosis and necrosis present only the two extremes of a continuum of different modes of cell death. It has been experimentally shown that the same stimulus may either induce apoptosis or necrosis, depending on the metabolic situation or the intensity of the insult (Leist and Nicotera 1997; Nicotera and Leist 1997). This may be explained by some characteristics of the internal death program: this program does not seem to be strictly linear and sequential, but rather it involves various partially independent branches responsible for the different characteristic features of apoptotic cells (e.g., membrane changes and nuclear changes). The cell will die by pure apoptosis if this program can be run and terminated properly and undisturbed. In contrast, necrosis or intermediate forms are observed if the insult is so intense that only parts of the program can be executed before unspecific events (e.g., failure of ion pumps) lead to membrane rupture. Thus, many intermediate or even completely different morphological (Leist and Wendel 1996) variants 
of cell death may exist. In experimental studies on liver cell death, a continuum of different modes of cell demise is often observed (Bohlinger et al. 1995; Leist et al. 1996a; Oberhammer et al. 1996; Zeid et al. 1997; Fukuda et al. 1993; Ledda-Columbano et al. 1991; Columbano 1995). This may be explained by the recruitment of different execution mechanisms in cells exposed to different concentrations of toxins. An alternative explanation has been derived from studies of lymphocyte and neuronal death (Nicotera and Leist 1997). The metabolic situation of the cell, in particular the ATP content, may determine the shape and mode of cell demise. For example, when ATP levels were experimentally reduced, typically apoptotic stimuli would result in necrosis (Leist et al. 1997b).

\section{3}

\section{Evidence for Apoptosis in the Liver}

Studies on the regressing or pathological liver and on isolated hepatocytes have initially contributed largely to the identification and characterization both of apoptosis and necrosis (Svoboda et al. 1962; Klion and Schaffner 1966; Levy et al. 1968; Kehrer et al. 1990; Orrenius et al. 1989; Kerr 1971). However, due to its inconspicuous characteristics the widespread occurrence and relevance of apoptosis for human pathology has been generally appreciated only recently (Que and Gores 1996; Schulte-Hermann et al. 1995), in contrast to the early recognition of ischemic or necrotic cell death.

\section{1 \\ Historical Aspects}

Before the term apoptosis was coined (Kerr et al. 1972), the morphological appearance of this mode of cell death in the liver had been known as shrinkage necrosis, Councilman bodies, chromatolysis, acidophilic bodies, or eosinophilic single-cell necrosis, and apoptotic shrinkage of the chromatin was described as pyknosis (Biava and Mukhlova-Montiel 1965; Miyai et al. 1962; Moppert et al. 1967; Kerr 1971; Klion and Schaffner 1966; Svoboda et al. 1962; Child and Ruiz 1968). The earliest descriptions of hepatic apoptosis date back to 1890 with the characterization of histopathology due to yellow fever (Councilman 1890). Strong interest in hepatic apoptosis developed in the 1960 s and the state of the art at that 
time is compiled in the milestone review by Kerr et al. (1972). First evidence of intracellular mechanisms characteristic of apoptosis was found in 1970, when Williams described oligonucleosomal DNA fragmentation in embryonic liver (Williamson 1970). Despite the appearance of visionary and instructive reviews (Kerr et al. 1972; Wyllie et al. 1980; Searle et al. 1982, 1987), the field of apoptosis research hardly moved until the late 1980s, when new methodological approaches finally led to the explosive development seen today.

\section{2}

\section{Inflammation and Hepatic Apoptosis}

Apoptosis is a mode of cell death that does not generally favor ensuing inflammation. Accordingly, large numbers of hepatocytes may die by apoptosis without significant enzyme release or inflammation (Hully et al. 1994). On the other hand, inflammatory mediators often induce hepatocyte apoptosis. In the liver apoptosis and necrosis often occur simultaneously, especially with high intensity insults killing more than $20 \%$ of all hepatocytes within hours. Accordingly, apoptotic hepatocytes can be found simultaneously with typical signs of inflammation or hemorrhage.

The prototype of a general inflammatory stimulus is lipopolysaccharide (LPS). This substance has been demonstrated to induce murine hepatocyte apoptosis with concomitant necrosis upon injection of sublethal doses into mice (Levy et al. 1968). Upon injection of lethal doses, liver damage was predominantly necrotic (Bohlinger et al. 1996). In addition to LPS, hepatic inflammation may also be induced by injection of D-galactosamine (GalN). This prototype liver-specific toxin acts by sensitizing the liver towards the effects of endogenous or exogenously applied LPS (Galanos et al. 1979; review in Leist et al. 1995a) and has been shown to induce hepatocyte destruction and apoptosis (Reutter et al. 1968, 1970; Keppler et al. 1968).

In inflammatory conditions not directly induced by experimental inflammogens there is also evidence of hepatocyte apoptosis: Apoptosis is found during chronic active hepatitis (Kerr et al. 1979; Searle et al. 1982; Hiramatsu et al. 1994) and liver allograft rejection (Battersby et al. 1974; Searle and Balderson 1996; Krams et al. 1995; Searle et al. 1982). In addition, TNF is induced during acute hepatitis (Torre et al. 1994; Ding-feng et al. 1993) and type-2 autoimmune hepatitis is linked to CD95 mutation (Pensati et al. 1997). TNF is a powerful inflammogen and has been shown 
to be a potent inducer of hepatocyte apoptosis in sensitized and non-sensitized mice (Gantner et al. 1995b; Leist et al. 1994).

\section{3}

\section{Viral Disease and Apoptosis}

There is ample evidence of hepatocyte apoptosis in mouse and man during viral infection (Hiramatsu et al. 1994; Klion and Schaffner 1966; Svoboda et al. 1962; Child and Ruiz 1968; Kerr et al. 1979; Searle et al. 1982). Additional evidence for induction of liver damage possibly by hepatocyte apoptosis comes from the findings that viral infection strongly sensitizes the liver towards LPS toxicity (Gut et al. 1984; Mori et al. 1981), and that under defined experimental conditions injection of viral antigens can cause fulminant liver failure (Mori et al. 1981). Viral infection may result in hepatocyte apoptosis by three conceptionally different mechanisms: (1) Viruses may directly induce apoptosis of cells; (2) hepatocytes presenting viral peptides may be attacked by cytotoxic lymphocytes that kill their target cell by apoptosis (Kondo et al. 1997). Accordingly, lymphocytes are found in close association with apoptotic hepatocytes (Bathal et al. 1982; Galle et al. 1995); and (3) upon viral infection hepatocytes may become sensitive towards certain apoptosis-inducing cytokines. This concept is based on the following lines of evidence: Firstly, viruses may elicit the production and upregulation of proapoptotic cytokines and their receptors even within hepatocytes (González-Amaro et al. 1994; Hiramatsu et al. 1994; Galle et al. 1995); secondly, viral infection generally sensitizes cells towards TNF toxicity or TNF-induced apoptosis (Ohno et al. 1993; review in Wong et al. 1992; Rubin 1992). Accordingly, TNF is frequently virustatic. The sensitization of cells may be explained by the transcriptional inhibition of cell-specific RNA by viruses (Huang and Wagner 1965). Under the metabolic condition of transcriptional block hepatocytes are sensitized more than 10000 -fold towards TNF-induced apoptosis (Leist et al. 1994). In particular, it has been shown that expression of hepatitis B virus (HBV) or HBx protein sensitized cells dose-dependently towards the induction of apoptosis by TNF (Guilhot et al. 1996; Su and Schneider 1997) and expression of HBV protein in transgenic mice sensitized hepatocytes towards TNF- and interferon (IFN)- $\gamma$-induced apoptosis and liver damage (Gilles et al. 1992).

Control of viral infection by apoptosis as opposed to necrosis would provide a considerable advantage to the body. Viral particles would not be 
Table 2. Toxins, intercellular signaling, and hepatocyte apoptosis

\begin{tabular}{|c|c|c|c|c|c|}
\hline Toxin & $\begin{array}{l}\text { Immune } \\
\text { mediators }\end{array}$ & $\begin{array}{l}\text { Synergy with } \\
\text { LPS or TNF }\end{array}$ & Apoptosis & $\begin{array}{l}\text { DNA- } \\
\text { fragmentation }\end{array}$ & References \\
\hline Paracetamol & + & $n p$ & + & + & $\begin{array}{l}\text { Laskin et al. (1995); Ray et al. (1993, 1996); } \\
\text { Blazka et al. (1995, 1996) }\end{array}$ \\
\hline Cocaine & np & np & + & + & Cascales et al. (1994) \\
\hline Nitrosamine & np & $\mathrm{np}$ & + & + & $\begin{array}{l}\text { Pritchard and Butler (1989); Ray et al. (1992); } \\
\text { Shikata et al. (1996) }\end{array}$ \\
\hline Ethanol & + & + & + & np & $\begin{array}{l}\text { Adachi et al. (1994); Goldin et al. (1993); } \\
\text { Hansen et al. (1994); Koop et al. (1997); } \\
\text { Higuchi et al. (1996) }\end{array}$ \\
\hline D-Galactosamine & + & + & + & np & $\begin{array}{l}\text { Czaja et al. (1994); Keppler et al. (1968); } \\
\text { Galanos et al. (1979) }\end{array}$ \\
\hline $\mathrm{Pb}^{2+}$ (withdrawal) & $\mathrm{np}$ & + & + & $\mathrm{np}$ & $\begin{array}{l}\text { Honchel et al. (1991); Seyberth et al. (1972); } \\
\text { Selye et al. (1966); Columbano et al. (1985) }\end{array}$ \\
\hline Thioacetamide & np & np & + & $\mathrm{np}$ & Ledda-Columbano et al. (1991) \\
\hline$\alpha$-Amanitin & + & + & + & + & Leist et al. (1997a); Seyberth et al. (1972) \\
\hline Actinomycin D & + & + & + & + & Leist et al. (1994, 1995a, 1997a) \\
\hline Diethyldithiocarbamate & + & np & np & np & Ishiyama et al. (1995) \\
\hline Phalloidin & + & np & np & np & Barriault et al. (1995) \\
\hline $\mathrm{CCl}_{4}$ & + & + & + & np & $\begin{array}{l}\text { Czaja et al. (1994, 1995); Leach and Forbes } \\
\text { (1941); Nolan (1989); Shi et al. (1997) }\end{array}$ \\
\hline Cyproteroneacetate & + & $\begin{array}{l}\text { synergy with } \\
\text { TGF- } \beta\end{array}$ & + & np & Oberhammer et al. (1996) \\
\hline Heliotrine (pyrrolizidine) & np & $\mathrm{np}$ & + & $\mathrm{np}$ & Kerr (1969) \\
\hline Ischemia-reperfusion & np & np & + & + & Sasaki et al. (1996); Shimizu et al. (1996) \\
\hline Microcystine & + & $\mathrm{np}$ & np & np & Nakano et al. (1991) \\
\hline
\end{tabular}

${ }^{a}$ Non-parenchymal liver cells or immune mediators are involved in toxicity.

+ , Positive evidence; np, no obvious evidence published in the cited reference. 
released from dying cells, but rather be digested, after phagocytosis of the membrane-enclosed apoptotic bodies. In addition, viral DNA would be destroyed by the process of oligonucleosomal DNA-fragmentation, that is typically found in hepatocytes killed by TNF or CD95 (Leist et al. 1994, 1996a).

\section{4}

\section{Apoptosis Induced by Toxins and Organ Size Regression}

It was recognized (Kerr et al. 1972) very early that apoptosis is not only the physiological mode of cell death in tissue turnover and development, but it may also be induced by stressful stimuli, toxins, unfavorable environmental conditions, and organ size regression (Ledda-Columbano et al. 1996; Columbano et al. 1985; Kerr 1971; Bursch et al. 1992; Grasl Kraupp et al. 1994). Accordingly, a large number of toxins produce hepatocyte apoptosis (Table 2), often associated with concomitant necrosis. The significance of apoptosis has been little appreciated by many toxicologists in the past. However, in this field the distinction between apoptosis and necrosis may have major practical implications for the interpretation of tissue damage, of the mechanisms leading to cell death, and for the design of preventive therapies.

\section{4 \\ Hepatic Apoptosis Elicited by Cytokine Signaling}

\section{1 \\ Transforming Growth Factor- $\beta$}

Transforming growth factor (TGF) $\beta$ is involved in many inflammatory processes. However, it differs from classical proinflammatory cytokines since it may also have strong anti-inflammatory (Randow et al. 1995), cytoprotective (Prehn et al. 1994; Merrill and Zimmerman 1991), and growth regulatory functions (Bedossa et al. 1995). In the liver it acts as a negative regulator of hepatocyte growth (Bursch et al. 1992) and mediates collagen deposition by Ito cells and fibrosis (Weiner et al. 1990).

TGF- $\beta$ was identified as the first defined mediator eliciting hepatocyte apoptosis (Oberhammer et al. 1991-1993a). It seems to be involved in the normal growth regulation of the liver rather than in inflammatory or 
infectious hepatocyte apoptosis. In fact, TGF- $\beta$-induced hepatocyte apoptosis is counteracted by the inflammogen LPS (Martin-Sanz et al. 1996) possibly due to the induction of protective growth factors (Fabregat et al. 1996). Overexpression of TGF- $\beta$ in transgenic mice leads to multiple tissue lesions, including hepatocyte apoptosis (Sanderson et al. 1995). The acute hepatocyte toxicity of TGF- $\beta$ ( $\leq 16 \mathrm{~h}$ ) is relatively low (Oberhammer et al. 1992,1996 ) compared to that mediated by TNF or CD95L. However, the mechanism of apoptosis induction by the three cytokines may be similar as far as the activation of caspase-3-related proteases is concerned (Künstle et al. 1997; Rodriguez et al. 1996b; Rouquet et al. 1996b; Inayat-Hussain et al. 1997). The effects of TGF- $\beta$ after prolonged exposure seem to depend on the metabolic situation of the liver, e.g., TGF- $\beta$-induced apoptosis is greatly enhanced in vivo and in vitro by tumor promoters, cyproterone acetate treatment, or conditions of liver size regression (Oberhammer and Qin 1995; Oberhammer et al. 1993a, 1996). A specific characteristic of TGF- $\beta$ is the arrest of apoptotic DNA fragmentation at the level of $50-\mathrm{kbp}$ fragments in rat liver (Oberhammer et al. 1993b). This is an important example showing that oligonucleosomal DNA fragmentation is not generally required for the apoptotic process. In various hepatoma cell lines TGF- $\beta$ induces oligonucleosomal DNA fragmentation (Lin and Chou 1992 ), and the related protein activin induces murine hepatic apoptosis associated with oligonucleosomal DNA fragmentation (Hully et al. 1994).

\section{2}

\section{Tumor Necrosis Factor}

TNFs are cytokines produced mainly by macrophages and T-cells, but under certain metabolic conditions also by many other cell types. Soluble or membrane-bound (Ware et al. 1992) TNF- $\beta$ (also known as lymphotoxin- $\alpha$ ) acts on either TNF receptors (Stauber and Aggarwal 1989) or, in conjunction with lymphotoxin- $\beta$, on a specific lymphotoxin receptor (Crowe et al. 1994; Browning et al. 1993). TNF- $\alpha$ is initially expressed as a $26-\mathrm{kDa}$ membrane protein. Alternatively, the extracellular $17-\mathrm{kDa}$ part is released by a metalloproteinase (Mohler et al. 1994) into the circulation and acts as a trimer on TNF receptors. Both the membrane-bound form and the soluble form have been found to be involved in toxic and inflammatory processes. TNF- $\alpha$ (TNF) is an extremely pleiotropic mediator inducing hepatic acute phase response, hepatic regeneration and growth, stimulation of immune cells, upregulation of adhesion molecules, shock- 
like conditions, lipolysis, cachexia, tissue destruction, and apoptotic or necrotic cell death in various cell types (Beutler 1992; Aggarwal and Vilcek 1992). Its cellular effects are mediated by two receptors, i.e., the $55-\mathrm{kDa}$ TNF-RI and the 75-kDa TNF-RII (Lewis et al. 1991; Tartaglia and Goeddel 1992). Its signal transduction involves trimerization and consequent binding of intracellular proteins (Peter et al. 1996; Wallach et al. 1996; Wallach 1997; Darnay and Aggarwal 1997) to the cytoplasmic tail of the receptor. The coupling of TNF-RI by various adaptor proteins to distinct downstream signaling pathways has been characterized recently: One pathway ends with the activation of caspases, a second involves the generation of ceramide by neutral sphingomyelinase, a third involves Jun $\mathrm{NH}_{2}$-terminal kinase (JNK) activation, and a further one leads to the activation of the apoptosis-preventing transcription factor nuclear factor (NF)-KB (Z.G. Liu et al. 1996; Adam-Klages et al. 1996). The most relevant pathway for the initiation of cell death is the activation of caspases with the cleavage of caspase-8 (FLICE) and caspase-10 possibly constituting the first steps in a protease cascade (Boldin et al. 1996; Muzio et al.1996). This pathway seems to be autoinhibited by the presence of dominant negative variants of caspases in the cell (Wallach 1997; Irmler et al. 1997), that resemble the viral FLICE-inhibitory proteins (FLIPs) (Thome et al. 1997). In addition, mitochondrial alterations and signals are involved in the toxic effects of TNF in various cell types (Stadler et al. 1992; Higuchi et al. 1997; Lancaster et al. 1989; Pastorino et al. 1996). It is likely that the balance of all these pathways determines the cellular fate.

\subsection{1}

Studies in Hepatocyte Cultures

The study of TNF-induced apoptosis in isolated hepatocytes has been complicated by the fact that under standard short-term culture conditions, TNF alone induces no or only very a low percentage of hepatocyte death (Guilhot et al. 1996; Leist et al. 1994, 1995b; Stadler et al. 1992; Shinagawa et al. 1991). Cell death was only observed if TNF was present in excessively high concentrations in combination with IFN- $\gamma$ (Adamson and Billings 1992, 1993). Under very specialized culture conditions direct hepatocyte apoptosis by TNF is observed (Bour et al. 1996; Ohno and Maier 1995). This difficulty in studying TNF toxicity in hepatocyte cultures is due to the fact that TNF transmits simultaneously possibly cytotoxic signals, and induces various cytoprotective mechanisms, such as the activation of NF- 
KB (Z.G. Liu et al. 1996; Beutler 1992; Aggarwal and Vilcek 1992). When these effects are eliminated by blocking transcription, hepatocytes become extremely sensitive to TNF (Leist et al. 1994). Under these conditions $\geq 80 \%$ of all cells in culture were killed within $16 \mathrm{~h}$ as evidenced by enzyme leakage and loss of the ability to reduce tetrazolium salts. The typical features of cell death were chromatin condensation, budding of the cells, formation of crescent-shaped chromatin lumps and break-up of the chromatin in several apoptotic bodies. These structural changes occurred within hepatocytes which maintained their membrane integrity. In parallel to the structural changes and well before membrane lysis, the DNA fragments and a typical oligonucleosomal pattern of cleavage is observed. All these observations are characteristic of apoptotic cell death. Similar results, i.e., TNF-induced apoptotic cell death under the condition of transcriptional sensitization by actinomycin D (ActD) (Fig. 1), GalN, or $\alpha$ amanitin, were obtained in cultures of HepG2 human hepatoma cells (Leist et al. 1994, 1997a). Examination of the signal transduction showed

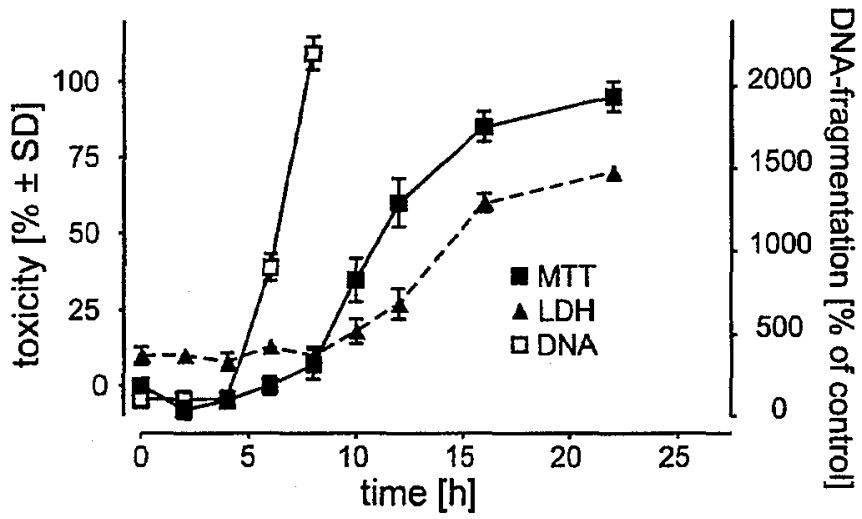

Fig. 1. Time course of cell death parameters in tumor necrosis factor (TNF)-induced apoptosis. Human hepatoma cells (HepG2) were incubated in the presence of $400 \mathrm{nM}$ actinomycin D plus $1.6 \mathrm{ng} / \mathrm{ml}$ recombinant human TNF (rhTNF)- $\alpha$. MTT-dye reduction (parameter of mitochondrial function), lactate dehydrogenase $(L D H)$ release (parameter for cell membrane rupture), and DNA fragmentation (parameter associated with typically apoptotic nuclear changes) were determined over a time period of $24 \mathrm{~h}$. As is characteristic of apoptotic cell death, DNA fragmentation always preceded the other death parameters. Similar findings have been obtained in primary hepatocyte cultures and murine livers 
that neither reactive oxygen species (ROS) nor NO, nor any of the various other well-known classical second messengers played a significant role as mediator of apoptotic death (Leist et al. 1994).

\section{2 .2}

In Vivo Studies in Mice

TNF has been shown to be hepatotoxic in man and mice (Jones and Selby 1989; Talmadge et al. 1987). Mice can be dramatically sensitized (up to 10000 -fold) by viral or bacterial infection or chemicals such as GalN. The aminosugar GalN is metabolized by enzymes of galactose metabolism that are only present in hepatocytes. High concentrations of GalN cause a selective depletion of uridine nucleotides in hepatocytes (Decker and Keppler 1974). Therefore, they cause a selective transcriptional inhibition in rat (Keppler et al. 1968) or murine (Leist et al. 1995a) liver. The mechanism of sensitization towards TNF by this substance is due to the selective facilitation of hepatocyte apoptosis caused by such a transcriptional block (Leist et al. 1994, 1995a). Accordingly, selective hepatocyte apoptosis in mice is also observed when GalN is substituted by the general and non-organ-specific transcriptional inhibitors ActD or $\alpha$-amanitin (Leist et al. 1994, 1995a, 1997a). Hepatocyte apoptosis in vivo develops analogously to that observed in vitro. Condensation, margination, and fragmentation of the chromatin, associated with oligonucleosomal DNA fragmentation precedes the loss of intracellular enzymes or a drop of total glutathione levels as parameters for membrane lysis or oxidative stress, respectively (Leist et al. 1994, 1995a,b). Histological examination of the late phases of TNF-induced liver damage in mice sensitized either by GalN or ActD showed widespread necrosis, inflammation, and hemorrhage. Thus, there is a sequence of events characterized by initially pure hepatocy te apoptosis that is followed by the simultaneous occurrence of apoptosis and necrosis as the liver damage proceeds to virtually complete destruction of the organ. Similar events are observed if livers are not sensitized by transcriptional inhibitors, but by preceding infection with Propionibacterium. acnes (Tsuji et al. 1997). Due to the complexity of the in vivo approach, it is difficult to decide at this point: (1) whether the occurrence of necrosis is due to secondary actions of TNF, possibly involving other cell types (Sauer et al. 1996; Hewett et al. 1993), (2) whether this is due to an inherent, but direct, necrosis-inducing activity of TNF, or (3) whether this is due to an incompletely terminated apoptotic program in an overstressed or energy-de- 
pleted tissue. There is some evidence for each of these possibilities. The last possibility is backed by findings (Leist and Nicotera 1997) that a variety of insults induce apoptosis at low intensities and cause necrosis if the intensity or duration of stress is increased (Dypbukt et al. 1994; Ankarcrona et al. 1995; Bonfoco et al. 1995; Shimizu et al. 1996; Oberhammer et al. 1996; Hartley et al. 1994; Lennon et al. 1991; Jensen et al. 1992; Corcoran and Ray 1992; Zeid et al. 1997; Fukuda et al. 1993; Ledda-Columbano et al. 1991). In addition, we found that typically apoptotic stimuli cause necrosis of T cells if their ATP levels are reduced (Leist et al. 1997b).

The large scale induction of hepatocyte apoptosis in vivo and in vitro suggests that a very effective endogenous death program is present in hepatocytes. This can be very easily triggered under certain metabolic conditions whereas it is efficiently repressed in others. When activated appropriately such a program may provide means to control viral infection and tumor growth in the organ that is most heavily exposed to toxins. If activated inappropriately, it may cause rapid destruction of the organ.

\subsection{3}

LPS-Induced Endogenous Production of TNF

In the studies described above, the actions of exogenously applied TNF were examined. Similar results were obtained in pathological model situations of endogenous TNF release. The liver harbors the largest pool of macrophages in the body and thus it is a potent TNF-producing organ (Leist et al. 1996b). Kupffer cells within the liver may produce TNF after direct stimulation, e.g., with LPS or after interaction with activated lymphocytes in a more complicated immunological setting (Gantner et al. 1996).

Accordingly, LPS injection into GalN-sensitized mice causes TNF release (Wendel 1990; Jilg et al. 1996) and the typical sequence of selective hepatocyte apoptosis followed by widespread necrosis and enzyme release from the liver (Leist et al. 1995a). Passive immunization of mice against TNF prevented apoptosis (Leist et al. 1995b), as well as transaminase release as a late sign of liver damage (Leist et al. 1995b; Tiegs et al. 1990). When doses of LPS 1000-fold higher than those given to sensitized animals were injected into non-sensitized mice the pathological findings were different (Bohlinger et al. 1996). Although a strictly TNF-dependent liver damage associated with DNA fragmentation was still observed, the incidence of hepatocyte apoptosis was very low. Liver cell types other than 
hepatocytes were affected and organ damage was widespread and far from being selective for the liver. Under such an excessive intensity of insult the selective triggering of an apoptotic program may be overridden by many other processes (Gutierrez-Ramos and Bluethmann 1997), such as complement activation, neutrophil immigration and activation (Sauer et al. 1996), ROS generation, and many more. In addition, a possibly initiated apoptotic process may not be fully executed until the stage of chromatin condensation due to energy failure (Leist and Nicotera 1997).

\subsection{4}

Induction of Endogenous TNF by Stimuli Other Than LPS

LPS is an excellent model stimulus for the induction of circulating TNF in animals and also in man (Zabel et al. 1989). The levels of serum TNF reached in humans exposed to LPS are sufficient to induce liver toxicity (Otto et al. 1996). Besides LPS, there is a large variety of other stimuli that induce TNF and cause fulminant apoptotic liver failure in GalN-treated mice. For example, hepatic apoptosis is also observed in GalN-pretreated mice when $T$ cells are polyclonally activated by stimulation of the $T$ cell receptor with an anti-CD3 antibody or the superantigen Staphylococcus aureus enterotoxin B (Gantner et al. 1995a). Both stimuli strongly increase the serum TNF concentrations of mice, and passive immunization against TNF prevented this rise, as well as apoptosis and other signs of liver damage. Similar forms of liver damage are also induced by malarial antigens (Bate et al. 1989; Jakobsen et al. 1997; Taverne et al. 1990) or constituents of Gram-positive bacteria (Miethke et al. 1992, 1993; Sparwasser et al. 1997). Thus, it seems that whenever circulating TNF is induced in GalNsensitized mice, liver apoptosis will be observed (Leist et al. 1995a).

Some animal models exist in which liver damage is induced by endogenous TNF in the absence of transcriptional inhibitors. In one of them, liver damage associated with hepatocyte apoptosis is induced by the polyclonal T cell stimulator concanavalin A (ConA) (Gantner et al. 1995b). Again the rise of serum TNF, of apoptosis, and other signs of damage were not present in mice immunized against TNF. However, mechanisms of liver damage seem to be different from those observed in GalN/TNF models, including those where primarily $\mathrm{T}$ cells are activated. For instance, TNF- $\alpha$ -1 - mice are normally sensitive to ConA (Tagawa et al. 1997), whereas TNF-RI - /- mice are protected (Leist et al. 1995a, 1996a). Thus TNF- $\beta$ may play an important role in this model, at least when it has to compensate for 
lacking TNF- $\alpha$. In addition, it has been found that inhibition of the processing of the $26-\mathrm{kDa}$ membrane-bound TNF- $\alpha$ to its soluble form protected GalN-sensitized mice from LPS toxicity, but enhanced the liver damage in ConA-treated mice (Solorzano et al. 1997). Thus ConA hepatitis possibly involves signals of the membrane-bound form of TNF (Küsters et al. 1997) that preferentially activates TNF-RII (Grell et al. 1995). A further feature of ConA-induced liver damage is the dependence on IFN- $\gamma$ (Tagawa et al. 1997; Küsters et al. 1996; Watanabe et al. 1996). IFN- $\gamma$ may exert direct toxicity on hepatocytes (Morita et al. 1995). However, the more likely role of this cytokine is upregulation of $\mathrm{CD} 95$ or perforin-dependent pathways, which may both play some role in ConA-dependent hepatic apoptosis (Watanabe et al. 1996; Tagawa et al. 1997).

Another situation where TNF-dependent liver apoptosis is observed is in LPS-challenged mice pretreated with $P$. acnes (previously called Corynebacterium parvum) (Tsuji et al. 1997). The pretreatment strongly increases production of TNF (Moldawer et al. 1987) and of IFN- $\gamma$ (Katschinski et al. 1992). In this complex model, hepatocyte apoptosis may be dependent on TNF-R and on CD95 since toxicity is considerably reduced in CD95-deficient mice or when the activation of CD95 is inhibited (Tsuji et al. 1997; Kondo et al. 1997).

\section{3}

\section{CD95 (fas/APO-1)}

CD95 (Nagata and Golstein 1995; Nagata 1997; Stanger 1996) is the nomenclature name for a cell surface receptor structurally homologous to TNFRI that was initially identified under the names APO-1 (Oehm et al. 1992) and fas (Yonehara et al. 1989). It shares with TNF-RI a short intracellular domain called the "death domain" (Tartaglia et al. 1993; Itoh and Nagata 1993). Upon ligand binding and trimerization of the receptor a death-inducing signaling complex (DISC) is formed by association of several molecules to the death domain (Peter et al. 1996). Following DISC formation a protease cascade involving caspases is triggered (Boldin et al. 1996; Muzio et al. 1996). The CD95 system seems to be less pleiotropic than the TNF/TNF-R system and cell death mediated by CD95 is generally apoptotic. 
4.3.1

Studies in Hepatocyte Cultures

It was shown that injection of an agonistic monoclonal antibody against CD95 (Jo-2) into mice was lethal and associated with fulminant hemorrhagic hepatic failure (Ogasawara et al. 1993). Histological examination of these livers showed apoptotic hepatocytes. In order to find out whether these effects of Jo-2 were mediated directly or via other cell types and/or mediators, the action of this antibody was examined directly on primary murine hepatocytes (Leist et al. 1996a). Analogously to the TNF model a typical sequence of apoptotic events was observed with chromatin and DNA changes preceding the loss of membrane integrity and mitochondrial function. Similar results were obtained in primary human hepatocytes (Galle et al. 1995). Notably, murine hepatocyte apoptosis induced by CD95 stimulation did not require any sensitization of the cells. CD95-induced apoptosis in HepG2 human hepatoma cells, however, required sensitization by ActD or bleomycin (Galle et al. 1995; Künstle et al. 1997). These studies suggest that hepatocytes express a second receptor that can directly trigger programmed cell death.

\subsection{2}

In Vivo Studies in Mice

RNAse protection assays showed that $\mathrm{CD} 95$ is highly expressed in murine livers starting at embryonic stages, whereas RNA for the CD95L was not detectable in untreated mice (French et al. 1996). There are situations when CD95L can be upregulated in the liver, e.g., after transformation to hepatocellular carcinoma (Strand et al. 1996). Upregulation may also occur during infection/inflammation in viral or alcoholic liver disease (Galle et al. 1995), or possibly near the central vein, a region that is thought to be specialized for elimination of aged hepatocytes and where the apoptotic index is increased compared to other liver regions (Benedetti et al. 1988). Correspondingly, mice with a $\mathrm{CD} 95$ null mutation show liver hyperplasia due to a lack of this death pathway (Adachi et al. 1995).

CD95 expressed in the liver is functional as an apoptosis-triggering-receptor, since the liver is the major target organ affected by systemic injection of Jo-2 (Ogasawara et al. 1993). It was shown that apoptotic liver damage also occurred after injection of the soluble CD95 ligand (CD95L) itself (Rensing-Ehl et al. 1995; Tanaka et al. 1997). The time course of 
various cell death parameters, and the question of whether the liver could be sensitized to CD95 triggered apoptosis by GalN was also examined. Analogous to the in vitro situation, only a minor sensitizing effect of GalN towards CD95-mediated liver damage was found, but the sequence of events (chromatin changes, oligonucleosomal DNA fragmentation, and subsequent enzyme release) was similar to that seen with GalN plus TNF (Leist et al. 1996a). Strong evidence for endogenously formed CD95L in hepatitis comes from studies with models where IFN- $\gamma$ is strongly induced. For example, liver damage due to $P$. acnes plus LPS seems to be mediated in part by CD95 (Kondo et al. 1997; Tagawa et al. 1997) and $P$. acnes infection strongly sensitizes the liver towards soluble CD95L (Tanaka et al. 1997). In addition it has been demonstrated that cytotoxic $T$ cells specific for hepatitis B virus antigen killed infected hepatocytes in a CD95-dependent manner (Kondo et al. 1997).

\section{4 \\ Delimitation of the CD95/CD95L System and the TNF-R/TNF System}

Due to the structural homology of CD95 with TNF-RI and CD95L with TNF and because of the functional redundancy there were early suggestions that these systems would not act independently. This question was examined by using mice or hepatocytes from mice (Fig. 2) that lacked either functional CD95 (lpr) or TNF-RI (tnf- $1^{\circ}$ ) or TNF-RII (tnf-R2 ${ }^{\circ}$ ) (Leist et al. 1996a).

- Hepatocytes from lpr mice reacted toward TNF just as wild-type (wt) mice, but were insensitive towards CD95 stimulation. Similar results were obtained in vivo: lpr mice reacted normally towards exogenously injected TNF or after endogenous TNF-induction due to ConA injection, whereas they were insensitive towards CD95 stimulation.

- In complementary experiments hepatocytes from tnf-r $1^{\circ}$ mice were used (Leist et al. 1995b, 1996a). They were completely insensitive towards TNF, but normally susceptible to CD95 stimulation. Similar results were obtained in vivo (Leist et al. 1995b, 1996a; Tsuji et al. 1997).

- In a third line of experiments, the role of TNF-RII was tested. Hepatocytes from tnf-r $2^{\circ}$ mice were normally sensitive towards CD95 stimulation and exposure to TNF in vivo or in vitro. In other words, TNF-RII does not seem to play a major role in the induction of apoptosis by TNF. The transmission of the TNF death signal in hepatocytes by TNF-RI 


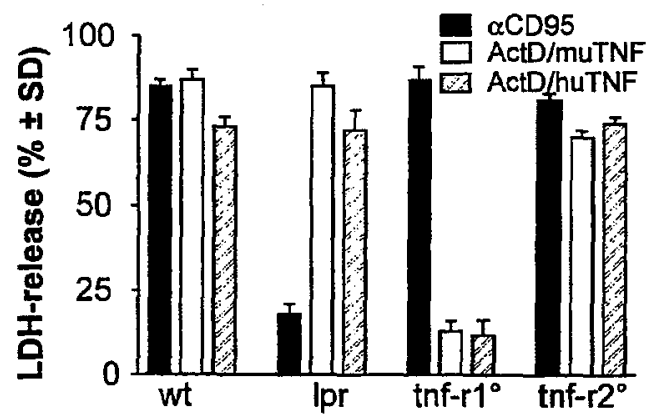

Fig. 2. Tumor necrosis factor (TNF)- or $\alpha \mathrm{CD} 95$-induced cytotoxicity in hepatocyte cultures. Hepatocytes from genotypically different mice [wt (wild-type), lpr (mice

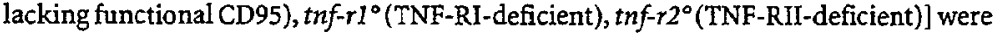
incubated with $333 \mathrm{nM}$ actinomycin $\mathrm{D}($ ActD) plus $100 \mathrm{ng} / \mathrm{ml}$ murine TNF- $\alpha$ (ActD/muTNF) or human TNF- $\alpha$ (ActD/huTNF) or $100 \mathrm{ng} / \mathrm{ml}$ agonistic anti-CD95 monoclonal antibody ( $\alpha C D 95)$. Cell death was determined $16 \mathrm{~h}$ after the start of the incubation by measurement of lactate dehydrogenase $(L D H)$ release. $\mathrm{LDH}$ release of unstimulated cultures was $18 \% \pm 2 \%$

alone is further suggested by the fact that human TNF (which binds to the murine TNF-RI, but not to the murine TNF-RII) induces murine hepatocyte apoptosis in vivo and in vitro (Leist et al. 1995b) (Fig. 2).

These studies strongly suggest that two fully independent receptor-ligand systems control hepatocyte apoptosis (Fig. 3). Additional evidence is provided by the observations that TNF apoptosis is modulated by GalN or variable ambient oxygen tensions, whereas that induced by $\mathrm{CD} 95$ stimulation is not (Leist et al. 1996a). Furthermore, the inhibition profile upon immunological, pharmacological, or genetic intervention differs between the two stimuli.

\section{5}

\section{Mechanisms and Modulation of Hepatic Apoptosis}

Modulation of hepatic apoptosis is desirable in disease control. Conversely, important mechanistic information can be derived from genetic, pharmacological, and immunologic intervention studies in disease models. 

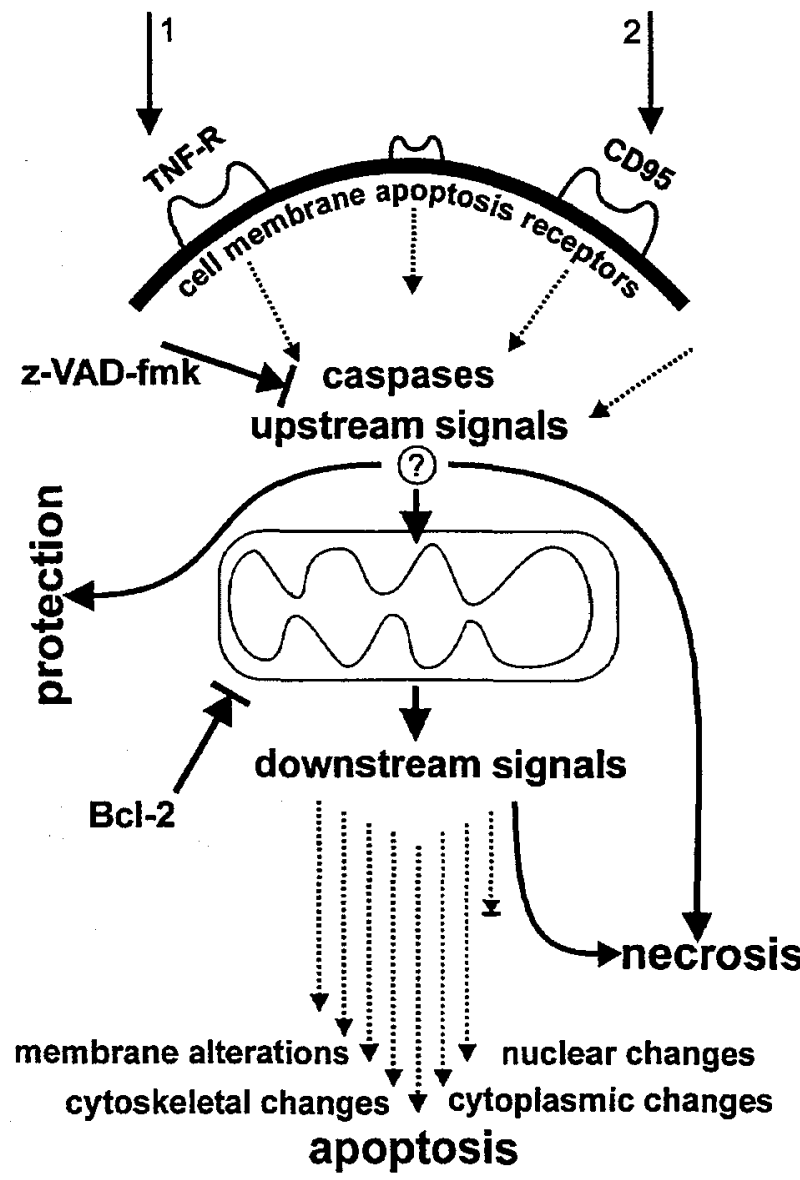

Fig. 3. Possible pathways of cytokine-induced hepatocyte death. Tumor necrosis factor receptor $(T N F-R)$ and $C D 95$ stimulated by independent signals $(1,2)$ activate signaling proteases such as caspase- 8 . This step is experimentally inhibited by caspase inhibitors such as z-VAD-fmk which protect hepatocytes. An irreversible step may include mitochondrial alterations and release of downstream signals such as cytochrome-c or apoptosis-inducing factor that would cause the activation of caspase- 3 and/or other proteases. Completion of all downstream steps results in apoptosis and failure to do so would result in necrosis or in cell death of intermediate morphology 


\section{1}

\section{Key Mechanisms of Apoptosis}

There is an overwhelming wealth of studies on either hepatocyte necrosis or on non-hepatocyte apoptosis. However, information on specific mechanisms of apoptosis in primary hepatocytes in vitro or in experimental animals in vivo is relatively sparse. Unlike the situation in many leukemic/tumor cell lines that mostly die by apoptosis, triggering of cell death in hepatocytes by a variety of stimuli often results in necrosis (Rosser and Gores 1995). This does not necessarily imply a different "death program" in hepatocytes, since apoptosis and necrosis are neither mechanisms of cell death nor do they allow conclusions on the mechanism having led to cell death. In fact, similar mechanisms seem to operate in hepatocytes as in many other well characterized cell types, although the final outcome may be apoptosis or necrosis.

The most critical event in apoptosis is currently thought to be the release of protein factors such as cytochrome $c$ or apoptosis-inducing factor (AIF) from mitochondria (Krippner et al. 1996; Golstein 1997; Zamzami et al. 1996; Kluck et al. 1997; Susin et al. 1996, 1997; Yang et al. 1997; X. Liu et al. 1996; Kroemer et al. 1997). The released factors seem to play a role in the activation of cell death execution mechanisms (Liu et al. 1997; Chinnaiyan et al. 1997a; Susin et al. 1997). Possibly, they form part of a so-called apoptosome complex that joins caspase precursors and bcl-2 related molecules via a linking protein that is called ced-4 in Caenorhabditis elegans and APAF-1 in eukaryotic cells (Chinnaiyan et al. 1997b; Hengartner 1997; Zou et al. 1997). APAF-1 or ced-4 may be allosterically regulated by ATP (Chinnaiyan et al. 1997a). The key process associated with the release of AIF is mitochondrial permeability transition (MPT), i.e., a breakdown of the diffusion barrier normally formed by the inner mitochondrial membrane and a resulting exchange of solutes up to a size of 3-10 kDa (Kroemer 1997a,b). MPT was in fact observed in livers from GalN-/LPS-challenged mice (Zamzami et al. 1996); mitochondria from such livers were able to induce nuclear apoptotic changes (Zamzami et al. 1996), and TNF has been shown to induce MPT in cells (Pastorino et al. 1996). MPT has also been observed in hepatocyte necrosis (Pastorino et al. 1993; Aguilar et al. 1996; Rosser and Gores 1995; Nieminen et al. 1995; Arora et al. 1997) and therefore seems to be independent of a specific mode of cell death. Another event, which has been thought to be a universal feature in apoptosis, is caspase activation. In fact, caspases are activated 
for example in CD95-triggered livers or primary hepatocytes (Rodriguez et al. 1996b; Leist et al. 1997c). However, both apoptosis and necrosis induced by $\mathrm{CD} 95$ in murine livers are inhibited by caspase inhibitors (Künstle et al. 1997). Moreover, there are also situations of hepatic apoptosis that do not involve caspase activation (Adjei et al. 1996). Possibly other proteases can substitute for caspases in the liver; for example, MPT has been shown to be induced in liver by calpains (Aguilar et al. 1996). Although protease activation seems to be a general theme of hepatocyte death, this may apply to both apoptosis and necrosis (Bronk and Gores 1993; Kwo et al. 1995; Nicotera et al. 1986a,b).

The complex situation can be explained by the following concept (see Fig. 3): (a) Various stimuli may induce the activation of proteases or other disturbances of cellular homeostasis. In the case of TNF or CD95 caspases 8 and 10, for example, would be activated. (b) Depending on the metabolic situation, hepatocytes would compensate the noxious insult, die rapidly by necrosis, or proceed to the next step of the death program. (c) MPT would mark the irreversible step in the sequence leading to cell death. (d) The metabolic situation of the cell and on additional effects of the death-inducing stimulus would then decide on the mode/shape of cell death. In the case of TNF/CD95 caspase-3-related proteases would be activated and usually apoptosis would ensue. In other cases only part of the set of downstream events triggered by MPT would occur. This would prevent the development of apoptotic morphology in the dying cell and thus lead to necrosis. Prevention of caspase-3 activation by ATP depletion in CD95treated Jurkat cells has been demonstrated to result in necrotic cell demise (Leist et al. 1997b).

\section{2}

\section{Pharmacological Prevention of Apoptosis}

Since the signal transduction of CD95 and TNF-RI has been identified only over the last few years, earlier intervention strategies could not follow a rational approach at the post-receptor level. Partial prevention of TNFinduced apoptosis in hepatocyte cultures and a reduction of liver damage in vivo was obtained by cyclic adenosine monophosphate (cAMP)-raising substances (Jilg et al. 1996; Gantner et al. 1997; Fladmark et al. 1997). A selective and potent reduction of TNF-induced apoptosis, but not of that induced by $\mathrm{CD} 95$, was obtained with fructose treatment (unpublished data), possibly due to the ATP-depleting action (Zeid et al. 1997; Valeri et al. 
1997) of this sugar. Liver damage due to CD95 activation was prevented by linomide, a substance possibly preventing the intracellular signaling of CD95 via the sphingomyelinase pathway (Redondo et al. 1996).

The most rational pharmacological approach in the past was based on the assumption that components of the death program may require de novo protein synthesis. ActD-sensitized murine hepatocyte cultures were indeed protected by various inhibitors of protein synthesis from TNF-induced apoptosis. Concentration-dependent protection was observed with cycloheximide, puromycin, ricin, and tunicamycin (Leist et al. 1994; Leist and Wendel 1995), which may suggest a requirement for de novo protein synthesis. However, cycloheximide may also induce apoptosis in whole livers (Ledda-Columbano et al. 1992; Furukawa et al. 1997) and alternative mechanisms of action have been suggested to explain cytoprotective effects of cycloheximide. These include upregulation of the anti-apoptotic protein $\mathrm{Bcl}-2$ and an improvement of endogenous antioxidant defense (Ratan et al. 1994). Protein synthesis inhibitors alone had hardly any sensitizing effect towards TNF in murine hepatocytes. Notably, when human hepatoma cells were used, they could be sensitized towards TNF by cycloheximide or ActD. Protein synthesis inhibitors did not protect from apoptosis elicited by $\mathrm{CD} 95$ stimulation, but rather had a sensitizing effect ( $\mathrm{Ni}$ et al. 1994).

In 1995, the intracellular pathway leading from TNF-R stimulation to apoptosis was shown in various cell types to involve activation and proteolytic action of caspases (Los et al. 1995; Tewari and Dixit 1995; Enari et al. 1995). This family of proteases is structurally related to the ced-3 cell death gene products of C. elegans (Kumar and Lavin 1996; Zhivotovsky et al. 1997; Henkart 1996; Patel et al. 1996). Inhibition of these proteases was tested as a potentially useful pharmacological approach to stop disease processes involving hepatocyte apoptosis (Künstle et al. 1997; Rouquet et al. 1996b; Rodriguez et al. 1996b). The results showed unambiguously that both TNF- and CD95-mediated hepatic apoptosis in mice was completely prevented when caspase activities were blocked. In addition, liver damage could even be stopped after its initiation by curative application of caspase inhibitors. Measurement of caspase activities in hepatocytes suggests a caspase-3-related enzyme as key mediator (Leist et al. 1997c). In agreement with this, measurement of caspase activities in vivo showed that this enzyme was particularly activated in the liver by CD95 stimulation (Rodriguez et al. 1996b). Finally, caspase inhibitors were shown not only to delay hepatotoxicity or to shift the toxicity to another organ, but rather, a 
single dose of inhibitor was sufficient to protect from an otherwise lethal challenge with TNF or $\alpha \mathrm{CD} 95$ and to ensure long-term survival (Fig. 4). Although the inhibitors used are still at an experimental stage, they suggest a novel pharmacological approach to apoptosis-related liver disease.

\section{3}

\section{Immunological and Genetic Modulation of Apoptosis}

TNF-induced murine hepatic apoptosis can be inhibited in vivo by immune modulators. For example, it has been shown that injection of the NO donor sodium nitroprusside or interleukin (IL)-1 completely prevented liver damage (Bohlinger et al. 1995; Leist et al. 1995a). Conversely, inhibition of endogenous NO formation significantly enhanced TNF-dependent liver damage (Bohlinger et al. 1995, 1996), so that NO production seems to represent an endogenous protective mechanism in the liver. In fact, direct protective effects of NO pretreatment against TNF-induced apoptosis have been observed with a liver-specific NO donor (Saavedra et al. 1997). Under this situation inhibition of apoptosis seems to have been due to upregula-

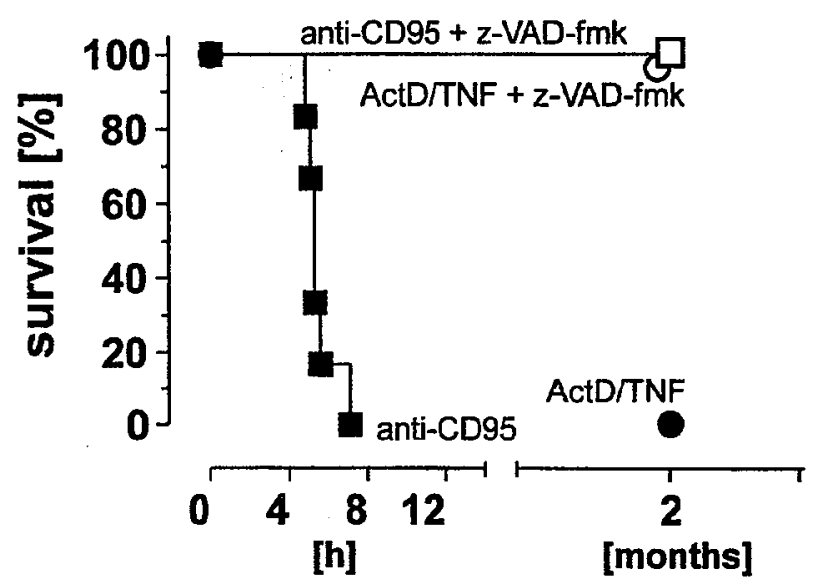

Fig. 4. Prevention by caspase inhibition of lethality due to apoptosis receptor stimulation. Mice were injected with actinomycin D/tumor necrosis factor (ActD/TNF) (circle) or anti-CD95 antibody (squares) with (open symbols) or without (solid symbols) pretreatment with the caspase inhibitor $(10 \mathrm{mg} / \mathrm{kg}) \mathrm{z}-\mathrm{VAD}$-fmk (intraperitoneally, $15 \mathrm{~min}$ before challenge). Survival was recorded over a period of 2 months 
tion of heat shock protein hsp70 (Kim et al. 1997). The protective effect of IL-1 in vivo is specific for TNF-induced toxicity since liver damage due to CD95 stimulation was not reduced by this cytokine (Leist et al. 1996a). In addition to direct effects of NO on hepatotoxicity, NO or IL-1 may have indirect in vivo actions, e.g., the synthesis of protective acute phase proteins (Libert et al. 1991, 1994; Van Molle et al. 1997), or the prevention of ischemia-reperfusion (Bohlinger et al. 1996).

Molecules modifying the CD95 apoptosis signal inside the cell have been examined by using transgenic mice. In an elegant approach $b c l-2$, a gene putatively controlling apoptosis at the mitochondrial level and upstream of caspase-3 activation, was overexpressed selectively in murine livers (Lacronique et al. 1996; Rodriguez et al. 1996a). Such transgenic mice were resistant to $\mathrm{CD} 95$-induced hepatic apoptosis and, in part, lethality. This approach shows that lethality induced by systemic CD95 stimulation in mice is to a large extent due to stimulation of apoptosis in hepatocytes and the subsequent liver failure.

In another approach a non-transforming mutant of simian virus (SV)$40 \mathrm{~T}$ antigen was overexpressed in mice. This molecule does not transform cells, but it is able to inactivate the putatively proapoptotic protein p53 (Rouquet et al. 1996a). Hepatocytes from such mice were protected from CD95-mediated apoptosis, but not from TNF. These findings suggest a variance of the two signal transduction pathways of TNF-RI and CD95, although both have caspase activation in common. The possible involvement of p53 in CD95 killing but not in TNF-triggered apoptosis suggests that hepatic apoptosis may be modulated differentially.

\section{6}

\section{Apoptosis in Hepatotoxicology}

Hepatotoxins may induce apoptosis (Corcoran et al. 1994; Columbano 1995) in two fundamentally different ways (Fig. 5): (1) In vitro, substances such as valinomycin (Sun et al. 1994), colchicine (Tsukidate et al. 1993), bile salts (Zeid et al. 1997; Botla et al. 1995; Kwo et al. 1995; Patel et al. 1994; Jones et al. 1997), and okadaic acid (Böe et al. 1991) directly induce cellular alterations that finally lead to apoptosis, possibly via the activation of caspases. (2) In vivo, the same direct mechanisms may operate. Alternatively, toxins may lead to the stimulation of hepatocytes with proapoptotic cytokines and sensitize them in parallel to the action of such mediators, 


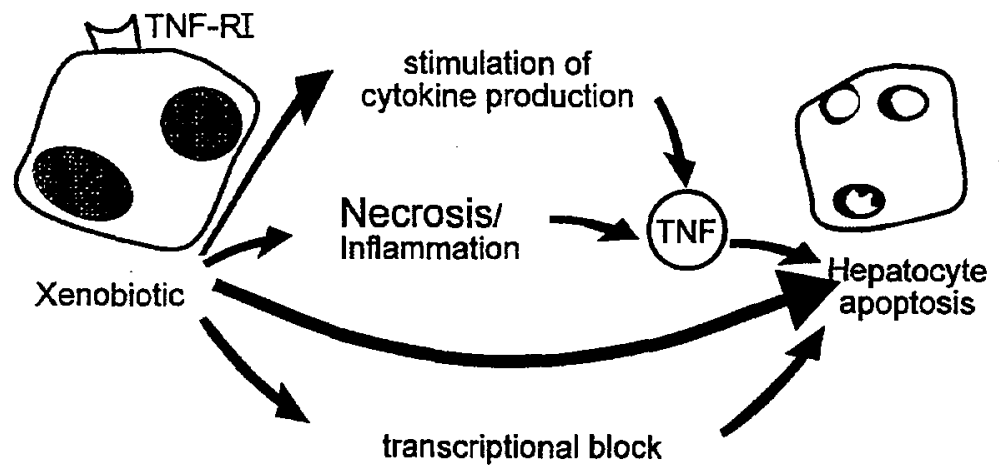

Fig. 5. Putative actions of toxins eventually causing apoptosis of hepatocytes. TNF, tumor necrosis factor; TNF-R1, tumor necrosis factor receptor-1

e.g., by weakening defense mechanisms or by inhibiting transcription. Particularly the second, indirect mode of action has found little attention and will be briefly reviewed below.

\section{1}

\section{Mediators Derived From Non-parenchymal Cells and Cytokines in Hepatotoxicalogy}

It seems that in vivo a large fraction of the most typical hepatotoxins alter the intercellular signaling (e.g., induce cytokine release or response) or act in synergy with intercellular signals (Table 2). This would imply that the explanation of their toxicity involves detailed intercellular molecular events in addition to their directly damaging effect on membranes or on vital structures within the ultimate target cell. The evidence for the involvement of immune mediators, non-parenchymal liver cells, and macrophage-derived products in toxicity has been compiled by Laskin and Pendino (1995). There are various studies showing that modulation of macrophage function or neutralization of immune mediators alters xenobiotic- induced toxicity (Table 2). One of the most prominent mediators is the proapoptotic cytokine TNF. 


\section{2}

\section{Toxin-Induced Apoptosis}

Evidence is accumulating to show that many xenobiotics cause apoptosis (Corcoran et al. 1994; Columbano 1995) or symptoms of hepatocyte apoptosis in rodents (see Table 2). This suggests that apoptosis in the liver is not restricted to physiological situations alone. The frequent co-occurrence of apoptosis and necrosis in the liver may imply that the default mode of demise for hepatocytes is apoptosis, as for many other cell types. However, many intoxications would damage hepatocytes so severely that the apoptotic program would not be continued to the end and cell death would take the shape of necrosis (Leist and Nicotera 1997).

\section{3}

\section{TNF as Mediator of Toxin-Induced Apoptosis}

If a single toxin releases TNF and simultaneously sensitizes cells towards the apoptotic actions of this cytokine, then TNF-induced hepatocyte apoptosis should contribute significantly to overall toxicity (see Fig. 5). For some toxins such a scenario has been demonstrated. For example, the toxicity of $\mathrm{CCl}_{4}$, the prototype of a directly acting hepatotoxin, is inhibited by scavenging of TNF with recombinant soluble TNF-receptor constructs (Czaja et al. 1995).

In another study, the role of TNF and hepatocyte apoptosis during the poisoning of mice with $\alpha$-amanitin or with ActD, respectively, was examined (Leist et al. 1997a). Indeed, the two toxins displayed similar actions on the liver. At low doses they induced hepatocyte apoptosis in vivo and in vitro highly synergistic with TNE. At high doses they induced liver damage alone that was associated with the occurrence of apoptotic hepatocytes and oligonucleosomal DNA fragmentation. This toxicity was inhibited by passive immunization of mice against TNF. Toxicity was also prevented by IL-1 pretreatment, which has been shown to prevent TNF-induced hepatocyte apoptosis (Bohlinger et al. 1996). The necessity of TNF for hepatotoxicity was further confirmed by the resistance of $\operatorname{tnf}-\mathrm{r} 1^{\circ}$ mice and the unaltered sensitivity of tnf-r $2^{\circ}$ mice to $\alpha$-amanitin. Thus, different lines of evidence suggest that hepatotoxicity of ActD or $\alpha$-amanitin, a prototype "direct-acting" hepatotoxin, involves the actions of TNF and the induction of apoptosis in hepatocytes. 
Also, the "direct" hepatotoxic effect of GalN was reexamined. Selective liver failure caused by this substance in rodents was suggested 30 years ago to represent a model for human viral hepatitis (Keppler et al. 1968). In fact, hepatocyte apoptosis (Councilman bodies) was noted to be one of the most conspicuous phenomena of GalN-induced pathology (Reutter et al. 1968, 1970; Keppler et al. 1968; Medline et al. 1970). A series of studies in the 1970 s and 1980 s showed that the substance exerted a very pronounced toxicity in synergy with endogenous and exogenous immune modulators (Grün and Liehr 1976; Liehr et al. 1978; Mihas et al. 1990; Galanos et al. 1979; Czaja et al. 1994). Finally, it was shown that GalN specifically sensitized mice to the lethality of TNF (Lehmann et al. 1987), which is due to selective liver failure (Tiegs et al. 1989) associated with apoptotic hepatocyte death (Leist et al. 1995a). In analogy to the studies on ActD and $\alpha$-amanitin toxicity, it was examined whether endogenous TNF would contribute to the putatively direct hepatotoxic effect of pure GalN. In fact, inhibition of liver failure and hepatocyte apoptosis by blunting the effects of endogenously formed TNF demonstrates the role of TNF in GalN hepatotoxicity (Fig. 6).

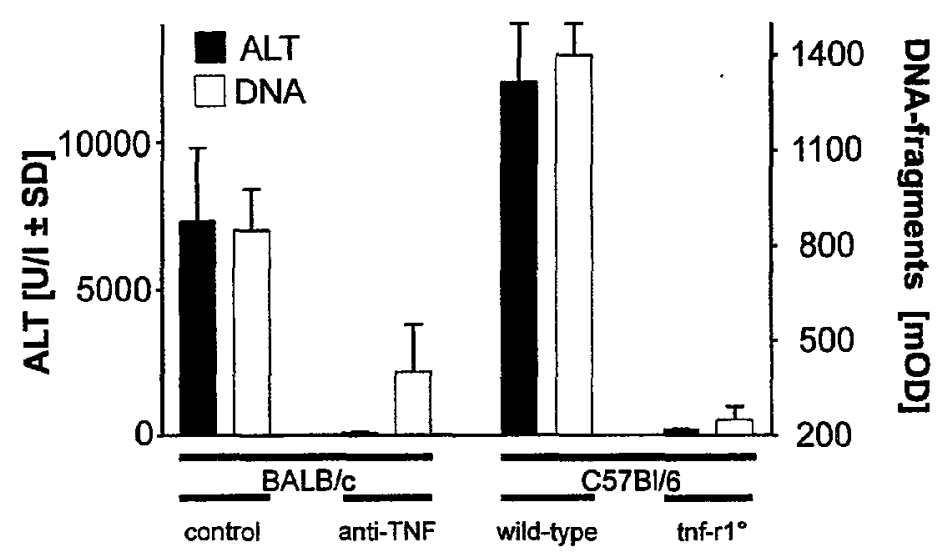

Fig. 6. The role of endogenous tumor necrosis factor (TNF) in D-galactosamine (GalN)induced liver damage. All mice were injected with $2.1 \mathrm{~g} / \mathrm{kg}$ GalN. Serum transaminases $(A L T)$ and hepatic DNA fragmentation were determined after $24 \mathrm{~h}$. Animals pretreated with neutralizing anti-TNF antibodies or mice lacking TNF receptor- $1\left(\operatorname{tnf}-r 1^{\circ}\right)$ were protected 
These findings appear to close a historic circle. Transcriptional inhibition by the xenobiotic GalN sensitizes hepatocytes to apoptosis triggered by endogenous TNF. As suggested initially, this may indeed resemble the situation during viral hepatitis. This may not only apply to the morphological appearance, but also to the mechanisms of hepatocyte death. The simple xenobiotic GalN may model some aspects of viral infection where transcription of the hepatocyte genome is partially blocked by viral protein synthesis and apoptosis is induced in virus-sensitized cells by endogenous TNF (Guilhot et al. 1996; Su and Schneider 1997).

Acknowledgements. We are grateful to Ms. C. Hoffmann for help in the preparation of the manuscript and to Prof. P. Nicotera for stimulating discussion. This work was supported by the Deutsche Forschungsgemeinschaft (grants We 686/17-1), as well as the Graduiertenkolleg "Biochemische Pharmakologie".

\section{References}

Adachi M, Suematsu S, Kondo T, Ogasawara J, Tanaka T, Yoshida N, Nagata S (1995) Targeted mutation in the Fas gene causes hyperplasia in peripheral lymphoid organs and liver. Nature Genet 11:294-300

Adachi Y, Bradford BU, Gao W, Bojes HK, Thurman RG (1994) Inactivation of Kupffer cells prevents early alcohol-induced liver injury. Hepatology 20:453-460

Adam-Klages S, Adam D, Wiegmann K, Struve S, Kolanus W, Schneider-Metgener J, Krönke M (1996) FAN, a novel WD-repeat protein, couples the p55 TNF-receptor to neutral sphingomyelinase. Cell 86:937-947

Adamson GM, Billings RE (1992) Tumor necrosis factor induced oxidative stress in isolated mouse hepatocytes. Arch Biochem Biophys 294:223-229

Adamson GM, Billings RE (1993) Cytokine toxicity and induction of NO synthase activity in cultured mouse hepatocytes. Toxicol Appl Pharmacol 119:100-107

Adjei PN, Kaufmann SH, Leung W-Y, Mao F, Gores G) (1996) Selective induction of apoptosis in Hep $3 \mathrm{~B}$ cells by toposiomerase I inhibitors: evidence for a protease-dependent pathway that does not activate cysteine protease P32. I Clin Invest 98:2588-2596

Aggarwal BB, Vilcek J (eds) (1992) Tumor necrosis factors. Structure, function and mechanisms of action. Dekker, New York

Aguilar HI, Botla R, Arora AS, BronkSF, Gores GJ (1996) Induction of the mitochondrial permeability transition by protease activity in rats: a mechanism of hepatocyte necrosis. Gastroenterology 110:558-566 
Ankarcrona M, Dypbukt JM, Bonfoco E, Zhivotovsky B, Orrenius S, Lipton SA, Nicotera $P$ (1995) Glutamate-induced neuronal death: a succession of necrosis or apoptosis depending on mitochondrial function. Neuron 15:961-973

Arora AS, Jones BJ, Patel TC, Bronk SF, Gores GJ (1997) Ceramide induces hepatocyte cell death through disruption of mitochondrial function in the rat. Hepatology 25:958-963

Barriault C, Audet M, Yousef IM, Tuchweber B (1995) Effect of agents which modify reticuloendothelial function on acute phalloidin-induced lethality and hepatotoxicity in mice. Toxicol Appl Pharmacol 131:206-215

Bate CA, Taverne J, Playfair JH (1989) Soluble malarial antigens are toxic and induce the production of tumor necrosis factor in vivo. Immunol 66:600-605

Bathal PS, Powell LW, Mackay IR (1982) Apoptosis in autoimmune chronic active Hepatitis (CAH). Hepatol 2:154-155

Battersby C, Egerton WS, Balderson G, Kerr JF, Burnett W (1974) Another look at rejection in pig liver homografts. Surgery 76:617-623

Bedossa P, Peltier E, Terris B, Franco D, Poynard T (1995) Transforming growth factor-beta 1 (TGF-betal) and TGF-betal receptors in normal, cirrhotic, and neoplastic human livers. Hepatology 21:760-766

Benedetti A, Jezequel AM, Orlandi F (1988) A quantitative evaluation of apoptotic bodies in rat liver. Liver 8:172-177

Beutler B (ed) (1992) Tumor necrosis factors. The molecules and their emerging role in medicine. Raven, New York

Biava C, Mukhlova-Montiel M (1965) Electron microscopic observation on councilman-like acidophilic bodies and other forms of acidophilic changes in human liver cells. Am J Pathol 46:775-802

Blazka ME, Wilmer JL, Holladay SD, Wilson RE, Luster MI (1995) Role of proinflammatory cytokines in acetaminophen hepatotoxicity. Toxicol Appl Pharmacol $133: 43-52$

Blazka ME, Elwell MR, Holladay SD, Wilson RE, Luster MI (1996) Histopathology of acetaminophen-induced liver changes: role of interleukin 1 alpha and tumor necrosis factor alpha. Toxicol Pathol 24:181-189

Böe R, T, Gjertsen, Vintermyr OK, Houge G, Lanotte M, Döskeland SO (1991) The protein phosphatase inhibitor okadaic acid induces morphological changes typical of apoptosis in mammalian cells. Exp Cell Res 195:237-246

Bohlinger I, Leist M, Barsig J, Uhlig S, Tiegs G, Wendel A (1995) Interleukin-1 and nitric oxide protect against tumor necrosis-factor alpha-induced liver injury through distinct pathways. Hepatology 22:1829-1837

Bohlinger I, Leist M, Gantner F, Angermüller S, Tiegs G, Wendel A (1996) DNA-fragmentation in mouse organs during endotoxic shock. Am J Pathol 149:1381-1393

Boldin MP, Goncharov TM, Goltsev YV, Wallach D (1996) Involvement of $\mathrm{MACH}$, a novel MORT1/FADD-interacting protease, in Fas/APO-1- and TNF receptor-induced cell death. Cell 85:803-815 
Bonfoco E, Krainc D, Ankarcrona M, Nicotera P, Lipton SA (1995) Apoptosis and necrosis: two distinct events induced respectively by mild and intense insults with NMDA or nitric oxide/superoxide in cortical cell cultures. Proc Natl Acad Sci USA 92:72162-72166

Botla R, Spivey JR, Aguilar H, Bronk SF, Gores GJ (1995) Ursodeoxycholate (UDCA) inhibits the mitochondrial membrane permeability transition induced by glychenodeoxycholate: a mechansism of UDCA cytoprotection. J Pharmacol Exp Ther 272:930-938

Bour ES, Ward LK, Cornman GA, Isom HC (1996) Tumor necrosis factor-alpha-induced apoptosis in hepatocytes in long-term culture. Am J Pathol 148:485-495

Bronk SF, Gores GJ (1993) pH-dependent nonlysosomal proteolysis contributes to lethal anoxic injury of rat hepatocytes. Am J Physiol 264:G744-G751

Browning JL, Ngam-ek A, Lawton P, DeMarinis J, Tizard R, Chow EP (1993) Lymphotoxin beta, a novel member of the TNF family that forms a heteromeric complex with lymphotoxin on the cell surface. Cell 72:847-856

Bursch W, Oberhammer F, Schulte-Hermann R (1992) Cell death by apoptosis and its protective role against disease. Trends Pharmacol Sci 13:245-251

Cascales M, Alvarez A, Gasco P, Fernandez Simon L, Sanz N, Bosca L (1994) Cocaineinduced liver injury in mice elicits specific changes in DNA ploidy and induces programmed death of hepatocytes. Hepatology 20:992-1001

Child P, Ruiz LA (1968) Acidophilic bodies. Their chemical and physical nature in patients with bolivian hemorrhagic fever. Arch Pathol 85:45-50

Chinnaiyan AM, Chaudhary D, O'Rourke K, Koonin EV, Dixit VM (1997a) Role of CED-4 in the activation of CED-3. Nature 388:728-729

Chinnaiyan AM, O'Rourke KO, Lane BR, Dixit VM (1997b) Interaction of ced-4 with ced-3 and ced-9: a molecular framework for cell death. Nature 275:1122-1126

Columbano A (1995) Cell death: current difficulties in discriminating apoptosis from necrosis in the context of pathological processes in vivo. J Cell Biochem 58:181-190

Columbano A, Ledda-Columbano GM, Coni PP, Faa G, Liguari C, Santa Cruz G, Pani $P$ (1985) Occurrence of cell death (apoptosis) during the involution of liver hyperplasia. Lab Invest 52:670-675

Corcoran GB, Ray SD (1992) Contemporary issues in toxicology. The role of the nucleus and other compartments in toxic cell death produced by alkylating hepatotoxicants. Toxicol Appl Pharmacol 113:167-183

Corcoran GB, Fix L, Jones DP, Moslen MT, Nicotera P, Oberhammer FA, Buttyan R (1994) Contemporary issues in toxicology. Apoptosis: molecular control point in toxicity. Toxicol Appl Pharmacol 128:169-181

Councilman WT (1890) Report on the etiology and prevention of yellow fever. In: Sternberg GM (ed) United states marine hospital service, Treasury Department, document no 1328. Government Printing Office, Washington DC, pp 151-159 (Public health bulletin 2) 
Crowe PD, VanArsdale TL, Walters BN, Ware CF, Hession C, Ehrenfels B, Browning IL, Din WS, Goodwin RG, Smith CA (1994) A lymphotoxin-beta-specific receptor. Science 264:707-710

Czaja MJ, Xu J, Ju Y, Alt E, Schmiedeberg P (1994) Lipopolysaccharide-neutralizing antibody reduces hepatocyte injury from acute hepatotoxin administration. Hepatology 19:1282-1289

Czaja MJ, Xu J, Alt E (1995) Prevention of carbon tetrachloride-induced rat liver injury by soluble tumor necrosis factor receptor. Gastroenterology 108:1849-1854

Darnay BG, Aggarwal BB (1997) Early events in TNF signaling: a story of associations and dissociations. J Leukoc Biol 61:559-566

Decker K, Keppler D (1974) Galactosamine hepatitis: key role of the nucleotide deficiency period in the pathogenesis of cell injury and cell death. Rev Physiol Biochem Pharmacol 71:77-100

Ding-feng Z, Hong R, Xiao-ping J, Ya-su Z (1993) Serum tumor necrosis factor (TNF) in the pathogenesis of clinical hepatic failure of $\mathrm{HCV}$ and/or $\mathrm{HBV}$ infection. Chin Med J 106:335-338

Dypbukt JM, Ankarcrona M, Burkitt M, Sjöholm A, Ström K, Orrenius S, Nicotera $P$ (1994) Different prooxidant levels stimulate growth, trigger apoptosis, or produce necrosis of insulin-secreting RINm5F cells. J Biol Chem 269:30533-30560

Enari M, Hug H, Nagata S (1995) Involvement of an ICE-like protease in fas-mediated apoptosis. Nature 375:78-81

Fabregat I, Sanchez A, Alvarez AM, Nakamura T, Benito M (1996) Epidermal growth factor, but not hepatocyte growth factor, suppresses the apoptosis induced by transforming growth factor-beta in fetal hepatocytes in primary culture. FEBS Lett 384:14-18

Fladmark KE, Gjertsen BT, Doskeland SO, Vintermyr OK (1997) Fas/Apo-1-induced apoptosis of primary hepatocytes is inhibited by CAMP. Biochem Biophys Res Commun 232:20-25

Flemming W (1885) Über die Bildung von Richtungsfiguren in Säugethiereiern beim Untergang Graaf scher Follikel. Arch Anat Physiol (Anat Abt) 221-244 + Taf X/XI

French LE, Hahne M, Viard I, Radlgruber G, Zanone R, Becker K, Müller C, Tschopp J (1996) Fas and Fas ligand in embryos and adult mice: ligand expression in several immune-privileged tissues and coexpression in adult tissues characterized by apoptotic cell turnover. J Cell Biol 133:335-343

Fukuda K, Kojiro M, Chiu J-F (1993) Demonstration of extensive chromatin cleavage in transplanted morris hepatoma 7777 tissue: apotosis or necrosis? Am J Pathol 142:935-946

Furukawa K, Estus S, Fu W, Mark RJ, Mattson MP (1997) Neuroprotective action of cycloheximide involves induction of bcl-2 and antioxidant pathways. J Cell Biol 136:1137-1149

Galanos C, Fretzdenberg MA, Reutter W (1979) Galactosamine-induced sensitization to the lethal effects of endotoxin. Proc Natl Acad Sci USA 76:5939-5943 
Galle PR, Hofmann WJ, Walczak $\mathrm{H}$, Schaller $\mathrm{H}$, Otto G, Stremmel W, Krammer PH, Runkel L (1995) Involvement of the CD95 (APO-1/Fas) receptor and ligand in liver damage. J Exp Med 182:1223-1230

Gantner F, Leist M, Jilg S, German PG, Freudenberg MA, Tiegs G (1995a) Tumor necrosis factor-induced hepatic DNA fragmentation as an early marker of T cell-dependent liver injury in mice. Gastroenterology 109:166-176

Gantner F, Leist M, Lohse AW, Germann PG, Tiegs G (1995b) Concanavalin A-induced $T$ Cell-mediated hepatic injury in mice: the role of tumor necrosis factor. Hepatology 21:190-198

Gantner F, Leist M, Küsters S, Vogt K, Volk D, Tiegs G (1996) T cell stimulus-induced crosstalk between lymphocytes and liver macrophages results in augmented cytokine release. Exp Cell Res 229:137-146

Gantner F, Küsters S, Wendel A, Hatzelmann A, Schudt C, Tiegs G (1997) Protection from $\mathrm{T}$ cell-mediated murine liver failure by phosphodiesterase inhibitors. J Pharmacol Exp Ther 280:53-60

Gilles PN, Guerrette DL, Ulevitch RJ, Schreiber RD, Chisari FV (1992) HBsAg retention sensitizes the hepatocyte to injury by physiological concentrations of interferongamma. Hepatology 16:655-663

Glücksmann A (1951) Cell death in normal vertebrate ontogeny. Biol Rev Camb Philos Soc 26:59-86

Goldin RD, Hunt NC, Clark J, Wickramasinghe SN (1993) Apoptotic bodies in a murine model of alcoholic liver disease: reversibility of ethanol-induced changes. J Pathol $171: 73-76$

Golstein P (1997) Controlling cell death. Science 275:1081-1082

González-Amaro R, Garcia-Monzón C, Garcia-Buey L, Moreno-Otero R, Alonso JL, Yagüe E, Pivel JP, López-Cabrera M, Fernandez-Ruiz E, Sánchez-Madrid F (1994) Induction of tumor necrosis factor alpha by human hepatocytes in chronic viral hepatitis. J Exp Med 179:841-848

Gräper L (1914) Eine neue Anschauung über physiologische Zellausschaltung. Arch Zellforsch 12:373-394

Grasl Kraupp B, Bursch W, Ruttkay Nedecky B, Wagner A, Lauer B, Schulte Hermann R (1994) Food restriction eliminates preneoplastic cells through apoptosis and antagonizes carcinogenesis in rat liver. Proc Natl Acad Sci USA 91:9995-9999

Grell $M$, Douni E, Wajant $H$, Löhden $M$, Clauss $M$, Maxeiner $B$, Georgopoulos S, Lesslauer W, Kollias G, Pfizenmaier K, Scheurich P (1995) The transmembrane form of tumor necrosis factor is the prime activating ligand of the $80 \mathrm{kDa}$ tumor necrosis factor receptor. Cell 83:793-802

Grün M, Liehr H (1976) Significance of endotoxemia in experimental "galactosaminehepatitis" in rat. Acta Hepato Gastroenterol 23:64-81

Guilhot S, Miller T, Cornman G, Isom HC (1996) Apoptosis induced by tumor necrosis factor-alpha in rat hepatocyte cell lines expressing Hepatitis B virus. Am J Pathol 148:801-814 
Gut J, Schmitt S, Bingen A, Anton M, Kirn A (1984) Probable role of endogenous endotoxins in hepatocytolysis during murine hepatitis caused by frog virus 3 . J Infect Dis 149:621-629

Gutierrez-Ramos JC, Bluethmann H (1997) Molecules and mechanisms operating in septic shock: lessons from knockout mice. Immunol Today 18:323-333

Hansen J, Cherwitz DL, Allen JI (1994) The role of tumor necrosis factor alpha in acute endotoxin-induced hepatotoxicity in ethanol-fed rats. Hepatology 20:461-474

Hartley A, Stone JM, Heron C, Cooper JM, Schapira AHV (1994) Complex I Inhibitors induce dose-dependent apoptosis in PC12 cells: relevance to Parkinson's disease. J Neurochem 63:1987-1990

Hengartner MO (1997) Apoptosis. CED-4 is a stranger no more. Nature 388:714-715

Henkart PA (1996) ICE family proteases: mediators of all apoptotic cell death? Immunity 4:195-201

Hewett JA, Jean PA, Kunkel SL, Roth RA (1993) Relationship between tumor necrosis factor-alpha and neutrophils in endotoxin-induced liver injury. Am J Physiol 256:G1011-G1015

Higuchi H, Kurose I, Kato S, Miura S, Ishii H (1996) Ethanol-induced apoptosis and oxidative stress in hepatocytes. Alcohol Clin Exp Res 20:340A-346A

Higuchi M, Aggarwal BB, Yeh ETH (1997) Activation of CPP32-like protease in tumor necrosis factor-induced apoptosis is dependent on mitochondrial function. J Clin Invest 99:1751-1758

Hiramatsu N, Hayashi N, Katayama K, Mochizuki K, Kawanishi Y, Kasahara A, Fusamoto H, Kamada $T$ (1994) Immunohistochemical detection of fas antigen in liver tissue of patients with chronic hepatitis C. Hepatology 19:1354-1359

Honchel R, Marsano L, Cohen D, Shedlofsky S, McClain CJ (1991) Lead enhances lipopolysaccharide and tumor necrosis factor liver injury. J Lab Clin Med 117:202-208

Huang AS, Wagner RR (1965) Inhibition of cellular RNA synthesis by non-replicating vesicular stomatitis virus. Proc Natl Acad Sci USA 54:1579

Hully JR, Chang L, Schwall RH, Widmer HR, Terrell TG, Gillett NA (1994) Induction of apoptosis in the murine liver with recombinant human activin $A$. Hepatology 20:854-861

Inayat-Hussain SH, Couet C, Cohen GM, Cain K (1997) Processing/activation of CPP32like proteases is involved in transforming growth factor betal-induced apoptosis in rat hepatocytes. Hepatology 25:1516-1526

Irmler $M$, Thome $M$, Hahne $M$, Schneider $P$, Hofmann $K$, Steiner V, Bodmer J- $L$, Schröter M, Burns K, Mattmann C, Rimoldi D, French LE, Tschopp J (1997) Inhibition of death receptor signals by cellular FLIP. Nature 388:190-195

Ishiyama $\mathrm{H}$, Ogino $\mathrm{K}$, Hobara $\mathrm{T}$ (1995) Role of Kupffer cells in rat liver injury induced by diethyldithiocarbamate. Eur J Pharmacol 292:135-141

Itoh N, Nagata S (1993) A novel protein domain required for apoptosis. Mutational analysis of human fas antigen. J Biol Chem 268:10932-10937 
Jakobsen PH, Bate CA, Taverne J, Playfair JH (1997) Malaria: toxins, cytokines and disease. Parasite Immunol 17:223-231

Jensen JC, Pogrebniak HW, Pass HI, Buresh C, Merino MJ, Kauffmann D, Venzon D, Langstein HN, Norton JA (1992) Role of tumor necrosis factor in oxygen toxicity. J Appl Physiol 5:1902-1907

Jilg S, Barsig J, Leist M, Küsters S, Volk H-D, Wendel A (1996) Enhanced release of interleukin-10 and soluble tumor necrosis factor receptors as novel principles of methylxanthine action in murine models of endotoxic shock. J Pharmacol Exp Ther 278:421-431

Jones AL, Selby P (1989) Tumor necrosis factor: clinical relevance. Cancer Surv 8:817-836

Jones BA, Rao YP, Stravitz RT, Gores GJ (1997) Bile salt-induced apoptosis of hepatocytes involves activation of protein kinase C. Am J Physiol 272:G1 109-G1115

Karvountzis GG, Redeker AG, Peters RL (1974) Long-term follow-up studies of patients surviving fulminant viral hepatitis. Gastroenterology 67:870-877

Katschinski T, Galanos C, Coumbos A, Freudenberg M (1992) Gamma interferon mediates proponibacterium acnes-induced hypersensitivity to lipopolysaccharide in mice. Infect Immun 60:1994-2001

Kehrer JP, Jones DP, Lemasters J), Farber JL, Jaeschke H (1990) Contemporary issues in toxicology. Mechanisms of hypoxic cell injury. Toxicol Appl Pharmacol 106:165-178

Keppler D, Lesch R, Reutter W, Decker K (1968) Experimental hepatitis induced by D-galactosamine. Exp Mol Pathol 9:279-290

Kerr JFR (1969) An electron-microscopic study of liver cell necrosis due to heliotrine. J Pathol 97:557-562

Kerr JFR (1971) Shrinkage necrosis: a distinct mode of cellular death. J Pathol 105:13-22

Kerr JF, Wyllie AH, Currie AR (1972) Apoptosis: a basic biological phenomenon with wide ranging implications in tissue kinetics. $\mathrm{Br}$ ) Cancer 26:239-247

Kerr JFR, Searle J, Halliday WJ, Roberts I, Cooksley WGE, Halliday JW, Holder L, Burnett W, Powell LW (1979) The nature of piecemeal necrosis in chronic active hepatitis. Lancet 2:827-828

Kim Y-M, de Vera ME, Watkins SC, Billiar TR (1997) Nitric oxide protects cuitured rat hepatocytes from tumor necrosis factor-alpha-induced apoptosis by inducing heat shock protein 70 expression. J Biol Chem 272:1402-1411

Klion FM, Schaffner F (1966) The ultrastructure of acidophilic bodies. Am J Pathol 48:755-765

Kluck RM, Bossy-Wetzel E, Green DR, Newmeyer DD (1997) The release of cytochrome $c$ from mitochondria: a primary site for bcl-2 regulation of apoptosis. Science 275:1132-1136

Kondo T, Suda T, Fukuyama H, Adachi M, Nagata $S$ (1997) Essential roles of the fas ligand in the development of hepatitis. Nat Med 3:409 413 
Koop DR, Klopfenstein B, limuro Y, Thurman RG (1997) Gadolinium chloride blocks alcohol-dependent liver toxicity in rats treated chronically with intragastric alcohol despite the induction of CYP2E1. Mol Pharmacol 51:944-950

Krams SM, Egawa H, Quinn MB, Villanueva JC, Garcia-Kennedy R, Martinez OM (1995) Apoptosis as a mechanism of cell death in liver allograft rejection. Transplantation 59:621-625

Krippner A, Matsuno-Yagi A, Gottlieb RA, Babior BM (1996) Loss of function of cytochrome $c$ in Jurkat cells undergoing Fas-mediated apoptosis. J Biol Chem 271:21629-21636

Kroemer G (1997a) Mitochondrial implication in apoptosis. Towards an endosymbiont hypothesis of apoptosis evolution. Cell Death Differ 4:443-456

Kroemer G (1997b) The proto-oncogene bcl-2 and its role in regulating apoptosis. Nat Med 3:614-620

Kroemer G, Zamzami N, Susin SA (1997) Mitochondrial control of apoptosis. Immunol Today 18:44-51

Kumar S, Lavin MF (1996) The ICE family of cysteine proteases as effectors of cell death. Cell Death Differ 3:255-267

Künstle G, Leist M, Uhlig S, Revesz L, Feifel R, MacKenzie A, Wendel A (1997) ICE-protease inhibitors block murine liver injury and apoptosis caused by $\mathrm{CD} 95$ or TNF-alpha. Immunol Lett 55:5-10

Küsters S, Gantner F, Kunstle G,Tiegs G (1996) Interferon gamma plays a critical rale in $T$ cell-dependent liver injury in mice initiated by concanavalin A. Gastroenterology 111:462-471

Küsters S, Tiegs G, Alexopoulou L, Pasparakis M, Douni E, Kuenstle G, Bluethmann H, Wendel A, Pfizenmaier K, Kollias G, Grell M (1997) In vivo evidence for a functional role of both tumor necrosis factor (TNF) receptors and transmembrane TNF in experimental hepatitis.. Eur I Immunol 27: (2870-2875)

Kwo P, Patel T, Bronk SF, Gores GJ (1995) Nuclear serine protease activity contributes to bile acid-induced apoptosis in hepatocytes. Am J Physiol 268:G613-G621

Lacronique V, Mignin A, Fabre M, Viollet B, Rouquet N, Molina T, Porteu A, Henrion A, Bouscary D, Varlet P, Joulin V, Kahn A (1996) Bcl-2 protects from lethal hepatic apoptosis induced by an anti-Fas antibody in mice. Nature Med 2:80-86

Lancaster JR, Laster SM, Gooding LR (1989) Inhibition of target cell mitochondrial electron transfer by tumor necrosis factor. FEBS Lett 248:169-174

Laskin DL, Pendino KJ (1995) Macrophages and inflammatory mediators in tissue injury. Annu Rev Pharmacol Toxicol 35:655-677

Laskin DL, Gardner CR, Price VF, Jollow DJ (1995) Modulation of macrophage functioning abrogates the acute hepatotoxicity of acetaminophen. Hepatology 21:1045-1050

Leach BE, Forbes JC (1941) Sulfonamide drugs as protective agents against carbon tetrachloride poisoning. Proc Soc Exp Biol Med 48:361-363 
Ledda-Columbano 'GM, Coni P, Curto M, Giacomini L, Faa G, Olivero S, Piacentini M, Columbano A (1991) Induction of two different modes of cell death, apoptosis and necrosis, in rat liver after a single dose of thioacetamide. Am J Pathol 139:1099-1109

Ledda-Columbano GM, Coni P, Faa G, Manenti G, Columbano A (1992) Rapid induction of apoptosis in rat liver by cycloheximide. Am J Pathol 140:545-549

Ledda-Columbano GM, Shinozuka H, Katyal SL, Columbano A, (1996) Cell proliferation, cell death and hepatocarcinogenesis. Cell Death Differ 3:17-22

Lehmann V, Freudenberg MA, Galanos C (1987) Lethal toxicity of lipopolysaccharide and tumor necrosis factor in normal and D-galactosamine-treated mice.J Exp Med 165:657-663

Leist M, Nicotera P (1997) The shape of cell death. Biochem Biophys Res Commun 236:1-9

Leist M, Wendel A (1995) Tunicamycin potently inhibits tumor necrosis factor-induced hepatocyte apoptosis. Eur J Pharmacol 292:201-204

Leist $M$, Wendel A (1996) A novel mechanism of murine hepatocyte death inducible by concanavalin A. J Hepatol 24:948-959

Leist M, Gantner F, Bohlinger I, German PG, Tiegs G, Wendel A (1994) Murine hepatocyte apoptosis induced in vitro and in vivo by TNF-alpha requires transcriptional arrest. J Immunol 153:1778-1787

Leist M, Gantner F, Bohlinger I, Tiegs G, Germann PG, Wendel A (1995a) Tumor necrosis factor-induced hepatocyte apoptosis precedes liver failure in experimental murine shock models. Am J Pathol 146:1220-1234

Leist M, Gantner F, Jilg S, Wendel A (1995b) Activation of the $55 \mathrm{kDa}$ TNF-receptor is necessary and sufficient for TNF-induced liver failure, hepatocyte apoptosis and nitrite release. J Immunol 154:1307-1316

Leist M, Gantner F, Künstle G, Bohlinger I, Tiegs G, Bluethmann H, Wendel A (1996a) The $55 \mathrm{kD}$ tumor necrosis factor receptor and CD95 independently signal murine hepatocyte apoptosis and subsequent liver failure. Mol Med 2:109-124

Leist M, Auer-Barth S, Wendel A (1996b) Tumor necrosis factor production in the perfused mouse liver and its pharmacological modulation by methylxanthines. I Pharmacol Exp Ther 276:968-976

Leist $M$, Gantner F, Naumann $H$, Bluethmann $H$, Vogt $K$, Brigelius-Flohe R, Nicotera P, Volk H, Wendel A (1997a) Tumor necrosis factor-induced apoptosis during poisoning of mice with hepatotoxins. Gastroenterology 112:924-935

Leist M, Single B, Castoldi AF, Kühnle S, Nicotera P (1997b) Intracellular ATP concentration: a switch deciding between apoptosis and necrosis. J Exp Med 185:1481-1486

Leist M, Single B, Künstle G, Volbracht C, Hentze H, Nicotera P (1997c) Apoptosis in the absence of poly-(ADP-ribose) polymerase. Biochem Biophys Res Commun 233:518-522

Lennon SV, Martin SJ, Cotter TG (1991) Dose-dependent induction of apoptosis in human tumor cell lines by widely diverging stimuli. Cell Prolif 24:203-214

Levy E, Slusser RJ, Ruebner BH (1968) Hepatic changes produced by a single dose of endotoxin in the mouse. Am J Pathol 52:477-502 
Lewis M, Tartaglia LA, Lee A, Bennett GL, Rice GC, Wong GH, Chen E, Goeddel DV (1991) Cloning and expression of CDNAs for two distinct murine tumor necrosis factor receptors demonstrate one receptor is species specific. Proc Natl Acad Sci USA 88:2830-2834

Libert C, Van Bladel S, Brouckaert P, Shaw A, Fiers W (1991) Involvement of the liver, but not of IL-6, in IL-1-induced desensitization to the lethal effects of tumor necrosis factor. J Immunol 146:2625-2632

Libert C, Brouckaert P, Fiers W (1994) Protection by alpha-1 acid-glycoprotein against tumor necrosis factor-induced lethality. J Exp Med 180:1571-1575

Liehr H, Grün M, Seelig H, R, Seelig, Reutter W, Heine W (1978) On the pathogenesis of galactosamine hepatitis. Virchows Arch [B] 26:331-344

Lin J-K, Chou C-K (1992) In vitro apoptosis in the human hepatoma cell line induced by transforming growth factor beta-1. Cancer Res 52:385-388

Liu X, Kim CN, Yang J, Jemmerson R, Wang X (1996) Induction of apoptotic program in cell-free extracts: requirement for dATP and cytochrome $c$. Cell 86:147-157

Liu X, Zou H, Slaughter C, Wang X (1997) DFF, a heterodimeric protein that functions downstream of caspase- 3 to trigger DNA fragmentation during apoptosis. Cell 89:175-184

Liu ZG, Hsu H, Goeddel DV, Karin M (1996) Dissection of TNF receptor 1 effector functions: JNK activation is not linked to apoptosis while NF-kB activation prevents cell death. Cell 87:565-576

Lockshin RA, Beaulaton J (1974) Programmed cell death. Life Sci 15:1549-1565

Lockshin RA, Williams CM (1965) Programmed cell death I. Cytology of degeneration in the intersegmental muscles of the pernyi silkmoth. J Insect Physiol 11:123-133

Los M, van de Craen M, Penning LC, Schenk $H$, Westendorp M, Baeuerle PA, Dröge W, Krammer PH, Flers W, Schulze-Osthoff $K$ (1995) Requirement of an ICE/CED-3 protease for Fas/APO-1-mediated apoptosis. Nature 375:81-83

Majno G, Joris I (1995) Apoptosis, oncosis, and necrosis. An overview of cell death. Am I Pathol 146:3-15

Martin-Sanz P, Diaz-Guerra MJ, Casado M, Bosca L (1996) Bacterial lipopolysaccharide antagonizes transforming growth factor beta 1 -induced apoptosis in primary cultures of hepatocytes. Hepatology 23:1200-1207

Medline A, Schaffner F, Popper H (1970) Ultrastructural features in galactosamine-induced hepatitis. Exp Mol Pathol 12:201-212

Merrill JE, Zimmerman RP (1991) Natural and induced cytotoxicity of oligodendrocytes by microglia is inhibitable by TGFbeta. GLIA 4:327-331

Miethke T, Wahl C, Heeg K, Echtenacher B, Krammer PH, Wagner H (1992) T cell-mediated lethal shock triggered in mice by the superantigen staphylococcal enterotoxin B: critical role of tumor necrosis factor. J Exp Med 175:91-98

Miethke T, Duschek K, Heeg K, Wagner H (1993) Pathogenesis of the toxic shock syndrome: $\mathrm{T}$ cell mediated lethal shock caused by the superantigen TSST-1. Eur J Immunol 23:1494-1500 
Mihas AA, Ceballos R, Mihas TA, Hirshowitz BI (1990) Modification of the hepatotoxicity of D-galactosamine in the rat by an anti-endotoxin. J Med 21:301-311

Miyai K, Slusser RJ, Ruebner BH (1962) Viral hepatitis in mice: an electron microscopic study. Exp Mol Pathol 2:464-480

Mohler KM, Sleath PR, Fitzner IN, Cerretti DP, Alderson M, Kerwar SS, Torrance DS, Otten-Evans C, Weerawarna T, Greenstreet K, Kronheim SR, Petersen M, Gerhart M, Kozlosky CJ, March CJ, Black RA (1994) Protection against a lethal dose of endotoxin by an inhibitor of tumor necrosis factor processing. Nature 370:218-220

Moldawer LL, Gelin J, Schersten T, Lundholm KG (1987) Circulating interleukin 1 and tumor necrosis factor during inflammation. Am J Physiol 253:R922-R928

Moppert J, Ekesparre D, Bianchi L (1967) Zur Morphogenese der eosinophilen Einzelzellnekrose im Leberparenchym des Menschen. Eine licht- und elektronenoptisch korrelierte Untersuchung. Virchows Arch Pathol Anat 342:210-220

Mori W, Aoki N, Shiga J (1981) Acute hepatic cell necrosis experimentally produced by viral agents in rabbits. Am J Pathol 103:31-38

Morita M, Watanabe Y, Akaike T (1995) Protective effect of hepatocyte growth factor on interferon-gamma-induced cytotoxicity in mouse hepatocytes. Hepatology 21:1585-1593

Muzio M, Chinnaiyan AM, Kischkel FC, O’Rourke K, Shevchenko A, Ni J, Scaffidi C, Bretz JD, Zhang M, Gentz R, Mann M, Krammer PH, Peter ME, Dixit VM (1996) FLICE, a novel FADD-homologous ICE/CED-3-like protease, is recruited to the CD95 (Fas/APO-1) death-inducing signaling complex. Cell 85:817-827

Nagata S (1997) Apoptosis by death factor. Cell 99:355-365

Nagata $S$, Golstein P (1995) The Fas death factor. Science 267:1449-1455

Nakano Y, Shirai M, Mori N, Nakano M (1991) Neutralization of microcystin shock in mice by tumor necrosis factor alpha antiserum. Appl Environ Microbiol 57:327-330

Ni R, Tomita Y, Matsuda K, Ichihara A, Ishimura K, Ogasawara I, Nagata S (1994) Fas-mediated apoptosis in primary cultured mouse hepatocytes. Exp Cell Res 215:332-337

Nicotera P, Leist M (1997) Energy supply and the shape of death in neurons and lymphoid cells. Cell Death Differ 4:435-442

Nicotera P, Hartzell P, Baldi C, Svensson S-A, Bellomo G, Orrenius S (1986a) Cystamine induces toxicity in hepatocytes through the elevation of cytosolic $\mathrm{Ca}^{2+}$ and the stimulation of a nonlysosomal proteolytic system. J Biol Chem 261:14628-14635

Nicotera P, Hartzell P, Davis G, Orrenius S (1986b) The formation of plasma membrane blebs in hepatocytes exposed to agents that increase cytosolic $\mathrm{Ca}^{2+}{ }^{2+}$ is mediated by the activation of a non-lysosomal proteolytic system. FEBS Lett 209:139-144

Nieminen A-L, Saylor AK, Tesfai SA, Herman B, Lemasters JJ (1995) Contribution of the mitochondrial permeability transition to lethal injury after exposure of hepatocytes to t-butylhydroperoxide. Biochem \} 307:99-106

Nissen F (1886) Über das Verhalten der Kerne in den Milchdrüsenzellen bei der Absonderung. Arch Mikroskop Anat 26:337-342 
Nolan JP (1989) Intestinal endotoxins as mediators of hepatic injury-an idea whose time has come again. Hepatology 10:887-891

Oberhammer F, Bursch W, Parzefall W, Breit P, Erber E, Stadler M, Schulte-Hermann $\mathrm{R}$ (1991) Effects of transforming growth factor beta on cell death of cultured rat hepatocytes. Cancer Res 51:2478-2485

Oberhammer FA, Pavelka M, Sharma S, Tiefenbacher R, Purchio AF, Bursch W, Schulte-Hermann R (1992) Induction of apoptosis in cultured hepatocytes and in regressing liver by transforming growth factor B1. Proc Natl Acad Sci USA 89:5408-5412

Oberhammer F, Bursch W, Tiefenbacher R, Fröschl G, Pavelka M, Purchio T, SchulteHermann R (1993a) Apoptosis is induced by transforming growth factor-betal within 5 hours in regressing liver without significant fragmentation of the DNA. Hepatology 18:1238-1246

Oberhammer F, Wilson JW, Dive C, Morris ID, Hickman JA, Wakeling AE, Walker PR, Sikorska M (1993b) Apoptotic death in epithelial cells: cleavage of DNA to 300 and/or $50 \mathrm{~kb}$ fragments prior to or in the absence of internucleosomal fragmentation. EMBO J 12:3679-3684

Oberhammer F, Nagy P, Tiefenbacher R, Fröschl G, Bouzanza B, Thorgeirsson SS, Carr $B$ (1996) The antiandrogen cyproterone acetate induces synthesis of transforming factor beta- 1 in the parenchymal cells of the liver accompanied by an enhanced sensitivity to undergo apoptosis and necrosis without inflammation. Hepatology 23:329-337

Oberhammer FA, Qin H (1995) Effect of three tumor promoters on the stability of hepatocyte cultures and apoptosis after transforming growth factor-betal. Carcinogenesis 16:1363-1371

Oehm A, Behrmann I, Kalk W, Pawlita M, Maier G, Klas C, Li-Weber M, Richards S, Dhein J, Trauth BC, Ponsting H, Krammer PH (1992) Purification and molecular cloning of the APO-1 cell surface antigen, a member of the tumour necrosis factor/nerve growth factor receptor family. J Biol Chem 267:10709-10715

Ogasawara J, Watanabe-Fukunaga R, Adachi M, Matsuzawa A, Kasugai T, Kitamura $Y$, Itoh $N$, Suda T, Nagata $S$ (1993) Lethal effect of the anti-fas antibody in mice. Nature 364:806-809

Ohno K, Maier P (1995) Tumor necrosis factor alpha differentially modulates the cellular response of rat hepatocytes in periportal- and pericentral-equivalent cultures. Eur J Pharmacol 292:205-214

Ohno K, Nakano T, Matsumoto Y, Watari T, Goitsuka R, Nakayama H, Tsujimoto H, Hasegawa A (1993) Apoptosis induced by tumor necrosis factor in cells chronically infected with feline immunodeficiency virus. J Virol 67:2429-2433

Orrenius S, McConkey DJ, Bellomo G, Nicotera P (1989) Role of $\mathrm{Ca}^{-{ }^{2+}}$ in toxic cell killing. Trends Pharmacol Sci 10:281-285

Otto F, Schmid P, Mackensen A, Wehr U, Seiz A, Braun M, Galanos C, Mertelsmann R, Engelhard R (1996) Phase II trial of intravenous endotoxin in patients with colorectal and non-small cell lung cancer. Eur J Cancer 32 A:1712-1718 
Pastorino JG, Snyder JW, Serroni A, Hoek JB, Farber JL (1993) Cyclosporin and carnitine prevent the anoxic death of cultured hepatocytes by inhibiting the mitochondrial permeability transition. J Biol Chem 268:13791-13798

Pastorino JG, Simbula G, Yamamoto K, Glascott Jr PA, Rothman RI, Farber IL (1996) The cytotoxicity of tumor necrosis factor depends on induction of the mitochondrial permeability transition. J Biol Chem 271:29792-29798

Patel T, Bronk SF, Gores GJ (1994) Increases of intracellular magnesium promote glycodeoxycholate-induced apoptosis in rat hepatocytes. J Clin Invest 94:2183-2192

Patel T, Gores GJ, Kaufmann SH (1996) The role of proteases during apoptosis. FASEB J 10:587-597

Pensati L, Costanzo A, Ianni A, Accapezzato D, Iorio R, Natoli G, Nisini R, Almerighi C, Balsano C, Vajro P, Vegnente A, Levrero M (1997) Fas/Apol mutations and autoimmune lymphoproliferative syndrome in a patient with type 2 autoimmune hepatitis. Gastroenterology 113:1384-1389

Peter ME, Kischkel FC, Hellbardt S, Chinnaiyan AM, Krammer PH, Dixit VM (1996) CD95(APO-1/Fas)-associating signalling proteins. Cell Death Differ 3:161-170

Pfitzner W (1886) Zur pathologischen Anatomie des Zellkerns. Virchows Arch Pathol Anat 103:275-300

Prehn JHM, Bindokas VP, Marcuccilli CJ, Krajewski S, Reed JC, Miller RJ (1994) Regulation of neuronal $\mathrm{Bcl}-2$ protein expression and calcium homeostasis by transforming growth factor type beta confers wide-ranging protection on rat hippocampal neurons. Proc Natl Acad Sci USA 91:12599-12603

Pritchard DJ, Butler WH (1989) Apoptosis - the mechanism of cell death in dimethylnitrosamine-induced hepatotoxicity. J Pathol 158:253-260

Que FG, Gores GJ (1996) Cell death by apoptosis: basic concepts and disease relevance for the gastroenterologist. Gastroenterology 110:1238-1243

Randow F, Syrbe U, Meisel C, Krausch D, Zuckermann H, Platzer C, Volk H-D (1995) Mechanism of endotoxin desensitization: involvement of interleukin 10 and transforming growth factor beta. J Exp Med 181:1887-1892

Ratan RR, Murphy TH, Baraban JM (1994) Macromolecular synthesis inhibitors prevent oxidative stress-induced apoptosis in embryonic cortical neurons by shunting cysteine from protein synthesis to glutathione. J Neurosci 14:4385-4392

Ray SD, Sorge CL, Kamendulis LM, Corcoran GB (1992) $\mathrm{Ca}^{++}$-activated DNA fragmentation and dimethylnitrosamine-induced hepatic necrosis: effects of $\mathrm{Ca}^{++}$-endonuclease and poly(ADP-ribose) polymerase inhibitors in mice. J Pharmacol Exp Ther 263:387-394

Ray SD, Kamendulis LM, Gurule MW, Yorkin RD, Corcoran GB (1993) $\mathrm{Ca}^{2+}$ antagonists inhibit DNA fragmentation and toxic cell death induced by acetaminophen. FASEB J 7:453-463

Ray SD, Mumaw VR, Raje RR, Fariss MW (1996) Protection of acetaminophen-induced hepatocellular apoptosis and necrosis by cholesteryl hemisuccinate pretreatment. J Pharmacol Exp Ther 279:1470-1483 
Redondo C, Flores I, Gonzalez A, Nagata S, Carrera AC, Merida I, Martinez AC (1996) Linomide prevents the lethal effect of anti-Fas antibody and reduces Fas-mediated ceramide production in mouse hepatocytes. J Clin Invest 98:1245-1252

Rensing-Ehl A, Frei K, Flury R, Matiba B, Mariani SM, Weller M, Aebischer P, Krammer PH, Fontana A (1995) Local Fas/APO-1 (CD95) ligand-mediated tumor cell killing in vivo. Eur J Immunol 25:2253-2258

Reutter W, Lesch R, Keppler D, Decker K (1968) Galactosamine-hepatitis. Naturwissenschaften 55:497

Reutter W, Bauer CH, Lesch R (1970) On the mechanism of action of galactosamine: different response to $\mathrm{D}$-galactosamine of rat liver during development. Naturwissenschaften 57:674-675

Rodriguez I, Matsuura K, Khatib K, Reed JC, Nagata S, Vassalli P (1996a) A bcl-2 transgene expressed in hepatocytes protects mice from fulminant liver destruction but not from rapid death induced by anti-Fas antibody injection. J Exp Med 183:1031-1036

Rodriguez I, Matsuura K, Ody C, Nagata S, Vassalli P (1996b) Systemic injection of a tripeptide inhibits the intracellular activation of CPP32-like proteases in vivo and fully protects mice against fas-mediated fulminant liver destruction and death. J Exp Med 184:2067-2072

Rosser BG, Gores GJ (1995) Liver cell necrosis: cellular mechanisms and clinical implications. Gastroenterology 108:252-275

Rouquet N, Allemand I, Grimber G, Molina T, Briand P, Joulin V (1996a) Protection of hepatocytes from Fas-mediated apoptosis by a non-transforming $\mathrm{SV} 40 \mathrm{~T}$-antigen mutant. Cell Death Differ 3:91 -96

Rouquet N, Pagès J-C, Molina T, Briand P, Joulin V (1996b) ICE inhibitor YVADcmk is a potent therapeutic agent against in vivo liver apoptosis. Curr Biol 6:1192-1195

Rubin BY (1992) TNF and viruses: multiple interrelationships. In: Aggarwal BB, Vilcek J (eds) Tumor necrosis factors. Structure, function and mechanisms of action. Dekker, New York, pp 331-340

Saavedra JE, Billiar TR, Williams DL, Kim YM, Watkins SC, Keefer LK (1997) Targeting nitric oxide (NO) delivery in vivo. Design of a liver-selective NO donor prodrug that blocks tumor necrosis factor-alpha-induced apoptosis and toxicity in the liver. J Med Chem 40:1947-1954

Sanderson M, Factor V, Nagy P, Kopp J, Kondaiah P, Wakefield L, Roberts AB, Sporn $M B$, Thorgeirsson SS (1995) Hepatic expression of mature transforming growth factor betal in transgenic mice results in multiple tissue lesions. Proc Natl Acad Sci USA 92:2572-2576

Sasaki H, Matsuno T, Tanaka N, Orita K (1996) Activation of apoptosis during the reperfusion phase after rat liver ischemia. Transplant Proc 28:1908-1909

Sauer A, Hartung T, Aigner J, Wendel A (1996) Endotoxin-inducible granulocyte-mediated hepatotoxicity requires adhesion and serine protease release. J Leukoc Biol 60:633-643

Saunders JW (1966) Death in embryonic systems. Science 154:604-612 
Savill J, Fadok V, Henson P, Haslett C (1993) Phagocyte recognition of cells undergoing apoptosis. Immunol Today 14:131-136

Schulte-Hermann R, Bursch W, Grasl-Kraupp B (1995) Active cell death (apoptosis) in liver biology and disease. Prog Liver Dis 15:1-35

Schwartz LM, Osborne BA (1993) Programmed cell death, apoptosis and killer genes. Immunol Today 14:582-590

Schwartz LM, Smith SW, Jones MEE, Osborne BA (1993) Do all programmed cell deaths occur via apoptosis? Proc Natl Acad Sci USA 90:980-984

Searle J, Kerr JFR, Bishop CJ (1982) Necrosis and apoptosis: distinct modes of cell death with fundamentally different significance. Pathol Ann 17:229-259

Searle J, Harmon BV, Bishop CI, Kerr JFR (1987) The significance of cell death by apoptosis in hepatobiliary disease. J Gastroenterol Hepatol 2:77-96

Searle JW, Balderson G (1996) Apoptosis as a mechanism of cell death in liver allograft rejection. Transplantation 61:168-169

Selye H, Tuchweber B, Bertok L (1966) Effect of lead acetate on the susceptibility of rats to bacterial endotoxins. J Bacteriol $91: 884-890$

Seyberth HW, Schmidt-Gayk H, HackentalE (1972) Toxicity, clearanceand distribution of endotoxin in mice as influenced by actinomycin $D$, cycloheximide, a-amanitin and lead acetate. Toxicon 10:491-500

Shi J, Fujeda H, Kokubo Y, Wake K (1997) Evidence of hepatocyte apoptosis in the rat liver after the administration of carbon tetrachloride (in press)

Shikata N, Oyaizu T, Senzaki H, Uemura Y, Tsubura A (1996) Liver apoptosis after dimethylnitrosamine administration in shrews. Exp Toxicol Pathol 48:307-311

Shimizu S, Eguchi Y, Kamiike W, Akao Y, Kosaka H, Hasegawa J, Matsuda H, Tsujimoto $Y$ (1996) Involvement of ICE family proteases in apoptosis induced by reoxygenation of hypoxic hepatocytes. Am J Physiol 271:G949-G958

Shimizu S, Eguchi Y, Kamiike W, Itoh Y, Hasegawa J-I, Yamabe K, Otsuki Y, Matsuda H, Tsujimoto $Y(1996)$ Induction of apoptosis as well as necrosis by hypoxia and predominant prevention of apoptosis by Bcl-2 and Bcl-xL. Cancer Res 56:2161-2166

Shinagawa T, Yoshioka $\mathrm{K}$, Kakumu S, Wakita T, Ishikawa T, Itoh Y, Takayanaki M (1991) Apoptosis in cultured rat hepatocytes: the effect of tumour necrosis factor alpha and interferon gamma. J Pathol 165:247-253

Solorzano CC, Ksontini R, Pruitt JH, Hess PJ, Edwards PD, Kaibara A, Abouhamze A, Auffenberg T, Galardy RE, Vauthey JN, Copeland EM III, Edwards CK III, Lauwers GY, CLare-Salzler M, MacKay SL, Moldawer LL, Lazarus DD (1997) Involvement of 26-kDa cell-associated TNF-alpha in experimental hepatitis and exacerbation of liver injury with a matrix metalloproteinase inhibitor. J Immunol 158:414-419

Sparwasser T, Miethke T, Lipford G, Erdmann A, Hacker H, Heeg K, Wagner H (1997) Macrophages sense pathogens via DNA motifs: induction of tumor necrosis factoralpha-mediated shock. Eur J Immunol 27:1671-1679

Stadler J, Bentz BG, Harbrecht BG, Di Silvio M, Curran RD, Billiar T, Hoffman RA, Simmons RL (1992) Tumor necrosis factor alpha inhibits hepatocyte mitochondrial respiration. Ann Surg 216:539-546 
Stanger BZ (1996) Looking beneath the surface: the cell death pathway of Fas/APO-1 (CD95). Mol Med 2:7-20

Stauber GB, Aggarwal BB (1989) Characterization and affinity cross-linking of receptors for human recombinant lymphotoxin (tumor necrosis factor-beta) on a human histiocytic lymphoma cell line, U-937. J Biol Chem 264:3573-3576

Strand S, Hofmann WJ, Hug H, Müller. M., Otto G, Strand D, Mariani SM, Stremmel W, Krammer PH, Galle PR (1996) Lymphocyte apoptosis induced by CD95 (APO1/Fas) ligand expressing tumor cells - a mechanism of immune evasion? Nature Med 2:1361-1366

Su F, Schneider RJ (1997) Hepatitis B virus $\mathrm{HBx}$ protein sensitizes cells to apoptotic killing by tumor necrosis factor alpha. Proc Natl Acad Sci USA 94:8744-8749

Sun DY, Jiang S, Zheng L, Ojcius DM, Young JD (1994) Separate metabolic pathways leading to DNA fragmentation and apoptotic chromatín condensation. J Exp Med 179:559-568

Susin SA, Zamzami N, Castedo M, Hirsch T, Marchetti P, Macho A, Daugas E, Geuskens M, Kroemer $G$ (1996) Bcl-2 inhibits the mitochondrial release of an apoptogenic protease. J Exp Med 184:1331-1341

Susin SA, Zamzami N, Castedo M, Daugas E, Wang H-G, Geley S, Fassy F, Reed JC, Kroemer $G$ (1997) The central executioner of apoptosis: multiple connections between protease activation and mitochondria in Fas/APO-1/CD95- and ceramideinduced apoptosis. J Exp Med 186:25-37

Svoboda D, Nielson A, Werder A, Higginson J (1962) An electron microscopic study of viral hepatitis in mice. Am J Pathol 41:205-224

Tagawa Y, Sekikawa K, Iwakura Y (1997) Suppression of concanavalin A-induced hepatitis in IFN-gamma $(-j-)$ mice, but not in TNF-alpha $(-/-)$ mice: role for IFNgamma in activating apoptosis of hepatocytes. J Immunol 159:1418-1428

Talmadge JE, Bowersox O, Tribble H, Lee SH, Shepard M, Liggitt D (1987) Toxicity of tumor necrosis factor is synergistic with gamma-interferon and can be reduced with cyclooxygenase inhibitors. Am I Pathol 128:410-425

Tanaka M, Suda T, Yatomi T, Nakamura N, Nagata S (1997) Lethal effect of recombinant human fas ligand in mice pretreated with Propionibacterium acnes. J Immunol 158:2303-2309

Tartaglia LA, Ayres M, Wong GHW, Goeddel DV (1993) A novel domain within the 55 kd TNF receptor signals cell death. Cell 74:845-853

Tartaglia LA, Goeddel DV (1992) Two TNF receptors. Immunol Today 13:151-153

Taverne J, Bate CA, Sarkar DA, Meager A, Rook GA, Playfair JH (1990) Human and murine macrophages produce TNF in response to soluble antigens of plasmodium falciparum. Parasite Immunol 12:33-43

Tewari M, Dixit VM (1995) Fas- and tumor necrosis factor-induced apoptosis is inhibited by the poxvirus crmA gene product. J Biol Chem 270:3255-3260

Thome M, Schneider P, Hofmann K, Fickenscher H, Meinl E, Neipel F, Mattmann C, Burns K, Bodmer J-L, Schröter M, Scaffidi C, Krammer PH, Peter ME, Tschopp J 
(1997) Viral FLICE-inhibitory proteins (FLIPs) prevent apoptosis induced by death receptors. Nature 386:517-520

Tiegs $G$, Wolter $M$, Wendel $A$ (1989) Tumor necrosis factor is a terminal mediator in galactosamine/endotoxin-induced hepatitis in mice. Biochem Pharmacol 38:627-631

Tiegs G, Niehörster M, Wendel A (1990) Leukocyte alterations do not account for hepatitis induced by endotoxin or TNF-alpha in galactosamine-sensitized mice. Biochem Pharmacol 40:1317-1322

Torre D, Zeroli C, Giola M, Ferrario G, Fiori GP, Bonetta G, Tambini R (1994) Serum levels of interleukin-1 alpha, interleukin-1 beta, interleukin-6, and tumor necrosis factor in patients with acute viral hepatitis. Clin Infect Dis 18:194

Tsuji $\mathrm{H}$, Harada A, Mukaida N, Nakanuma Y, Bluethmann $H$, Kaneko S, Yamakawa K, Nakamura S-I, Kobayashi K-I, Matsushima K (1997) Tumor necrosis factor receptor p55 is essential for intrahepatic granuloma formation and hepatocellular apoptosis in a murine model of bacterium-induced fulminant hepatitis. Infect Immun 65:1892-1898

Tsukidate K, Yamamoto K, Snyder JW, Farber JL (1993) Microtubule antagonists activate programmed cell death (apoptosis) in cultured rat hepatocytes. Am J Pathol 143:918-925

Valeri F, Boess F, Wolf A, Göldlin C, Boelsteri UA (1997) Fructose and tagatose protect against oxidative cell injury by iron chelation. Free Radic Biol Med 22:257-268

Van Molle W, Libert C, Fiers W, Brouckaert P (1997) Alpha 1-acid glycoprotein and alpha 1-antitrypsin inhibit TNF-induced but not anti-Fas-induced apoptosis of hepatocytes in mice. J Immunol 159:3555-3564

Virchow $\mathrm{R}$ (1858) Cellular pathology as based upon physiological and pathological histology. In: Birmingham AL (ed) Classics of medicine library, 2nd edn, p 361

Wallach $D$ (1997) Placing death under control. Nature 388:123-126

Wallach D, Boldin M, Goncharov T, Goltsev Y, Mett I, Malinin N, Adar R, Kovalenko A, Varfolomeev E (1996) Exploring cell death mechanisms by analyzing signaling cascades of the TNF/NGF receptor family. Behring Inst Mitt 97:144-155

Ware CF, Crowe PD, Grayson MH, Androlewicz MJ, Browning JL (1992) Expression of surface lymphotoxin and tumor necrosis factor on activated $T, B$, and natural killer cells. J Immunol 149:3881-3888

Watanabe $\mathrm{Y}$, Morita M, Akaike T (1996) Concanavalin A induces perforin-mediated but not fas-mediated hepatic injury. Hepatology 24:702-710

Weil M, Jacobson MD, Coles HSR, Davies T], Gardner RL, Raff KD, Raff MC (1996) Constitutive expression of the machinery for programmed cell death. J Cell Biol 133:1053-1059

Weiner FR, Giambrone M, Czaja MJ, Shah A, Annoni G, Takahashi S, Eghbali M, Zern MA (1990) Ito-cell gene expression and collagen regulation. Hepatology 11:111-120

Wendel A (1990) Biochemical pharmacology of inflammatory liver injury in mice. Methods Enzymol 186:675-680 
Williamson R (1970) Properties of rapidly labelled deoxyribonucleic acid fragments isolated from the cytoplasm of primary cultures of embryonic mouse liver cells. J Mol Biol 51:157-168

Wong GHW, Kamb A, Goeddel DV (1992) Antiviral properties of TNF. In: Beutler B (ed) Tumor necrosis factors. The molecules and their emerging role in medicine. Raven, New York, pp 371-382

Wyllie AH, Kerr JF, Currie AR (1980) Cell death: the significance of apoptosis. Int Rev Cytol 68:251-306

Yang J, Liu X, Bhalla K, Kim CN, Ibrado AM, Cai J, Peng T, Jones DP, Wang X (1997) Prevention of apoptosis by Bcl-2: release of cytochrome $c$ from mitochondria blocked. Science 275:1129-1132,

Yonehara S, Ishii A, Yonehara M (1989) A cell-killing monoclonal antibody (anti-Fas) to a celli surface antigen co-downregulated with the receptor of tumor necrosis factor. J Exp Med 169:1747-1756

Zabel P, Wolter DT, Schönharting MM, Schade UF (1989) Oxpentifylline in endotoxemia. Lancet II:1474-1477

Zamzami N, Susin SA, Marchetti P, Hirsch T, Gómez-Monterrey I, Castedo M, Kroemer G (1996) Mitochondrial control of nuclear apoptosis. J Exp Med 183:1533-1544

Zeid IM, Bronk SF, Fesmier PJ, Gores GJ (1997) Cycloprotection by fructose and other ketohexoses during bile salt-induced apoptosis of hepatocytes. Hepatol 25:81-86

Zhivotovsky B, Burgess DH, Vanags DM, Orrenius S (1997) Involvement of cellular proteolytic machinery in apoptosis. Biochem Biophys Res Commun 230:481-488

Zou H, Henzel WJ, Liu X, Lutschg A, Wang X (1997) Apaf-1, a human protein homologous to C. elegans CED-4, participates in cytochrome c-dependent activation of caspase-3. Cell 90:405-413

Editor-in-charge: Professor D. Pette 